\title{
AZ ARCFELISMERÉSI ZAVAROK OSZTÁLYOZÁSA A KIALAKULÁS OKA, AZ IDEGTUDOMÁNYI, VALAMINT A VISELKEDÉSES EREDMÉNYEK TÜKRÉBEN*
}

\author{
NÉMETH KORNÉL ${ }^{1,2}$ - ZIMMER MÁRTA ${ }^{1}$ \\ ${ }^{1}$ Budapesti Műszaki és Gazdaságtudományi Egyetem, Kognitív Tudományi Tanszék \\ ${ }^{2}$ Semmelweis Egyetem, Pszichiátriai és Pszichoterápiás Klinika \\ E-mail: knemeth@cogsci.bme.hu
}

Beérkezett: 2014. március 24. - Elfogadva: 2014. szeptember 01.

\begin{abstract}
A prosopagnosia az ismerős arcok felismerési zavara normál látási és kognitív funkciók ellenére. A zavar szerzett formája az occipito-temporalis területek károsodásának következtében alakul ki, míg a születéstöl meglévő zavar idegrendszeri háttere nagymértékü heterogenitást mutat. Az agykárosodási mintázat változatossága mellett a tünetek súlyosságában is nagy egyéni különbségeket találunk. Bár az elmúlt 20 évben az arcfelismerési zavar kutatását egyre nagyobb érdeklődés övezi, a vizsgálati eredmények alapján levonható következtetések általánosithatóságát limitálja, hogy ezek többnyire egyedi, elszigetelt esetekböl indulnak ki. Ha egyértelmü konklúzió nem rajzolódik is ki az ismert eredmények alapján, az mindenképpen megállapitható, hogy számos aspektus tekintetében a zavar alcsoportokra osztható. A tárgyfelismerési zavarok osztályozásának analógiájára felmerül az arcfelismerési zavarok apperceptív és asszociatív alcsoportokra bontásának lehetösége, valamint hogy a zavar akár spektrum jellegü is lehet. A prosopagnosia veleszületett típusában a generációkon át megjelenő esetek ráirányítják a figyelmet a genetikai eredet kérdésére. Jelen tanulmányban áttekintjük az arcfelismerési zavar csoportositásának lehetséges szempontjait. Továbbá az ismert esetek áttekintésével próbáljuk megmutatni a differenciálás szükségességét, valamint rávilágítunk azokra a szempontokra, amelyek szem elött tartásával a következö vizsgálatok során érdemi lépéseket tehetünk a zavar megismerése felé.
\end{abstract}

Kulcsszavak: arcfelismerési zavar, prosopagnosia, rejtett arcfelismerés, N170

Köszönet Kovács Gyulának hasznos kommentárjaiért.

A tanulmány az Országos Tudományos Kutatási Alap (ZM: OTKA; PD101499) támogatásával készült. 


\section{BEVEZETÉS}

Az arcok az identitás és érzelmi állapot felismerése esetén is elsődleges információforrást jelentenek, az egészséges arcészlelés ezért alapvető fontosságú azon faj egyedeinél, ahol a túlélési/szaporodási siker függ a szociális interakciók sikerességétől (AKeCHI, KikUChI, Tojo, OSANAI és HASEGaWA, 2014). Előfordul azonban, hogy ez az alapvető fontosságú arcfelismerési rendszer nem működik megfelelően, a zavar azonban nem egységes, számos megnyilvánulási formája ismert.

$\mathrm{Az}$ arcfelismeréssel kapcsolatos magyar nyelvű könyvekben, kézikönyvekben (lásd például RÉVÉSZ, 2010; SÉRA, 2008; ZIMMER, 2013) a prosopagnosia ismertetése, a zavarral kapcsolatos legújabb kutatási eredmények részletes, rendszerezett összefoglalása nem történt meg. Jelen tanulmány célja ezen kutatási eredmények áttekintése, és ezek alapján a zavar lehetséges osztályozási lehetőségeinek végiggondolása. Ez azonban nem lehetséges az ép arcészlelésre vonatkozó ismeretek, modellek rövid bemutatása nélkül.

\section{AZ EGÉSZSÉGES ARCÉSZLELÉS MODELLJEI - IDEGTUDOMÁNYI KORRELÁTUMOK}

Az eredetileg BRUCE és YOUNG (1986) által kidolgozott, majd mások által többször kiegészített arcfelismerési modell első állomása a strukturális kódolás (1. ábra; a modell átdolgozott változatát [3. ábra] lásd a tanulmány második felében, az 520. oldalon). A strukturális kódolás szakaszában a bejövő információ alapján egy nézőpontfüggő, az arc egészét (konfigurációját - a szemek, az orr és a száj T alakú elrendeződése) és az arcjegyeket is integráló, de az arckifejezéstől független repre-

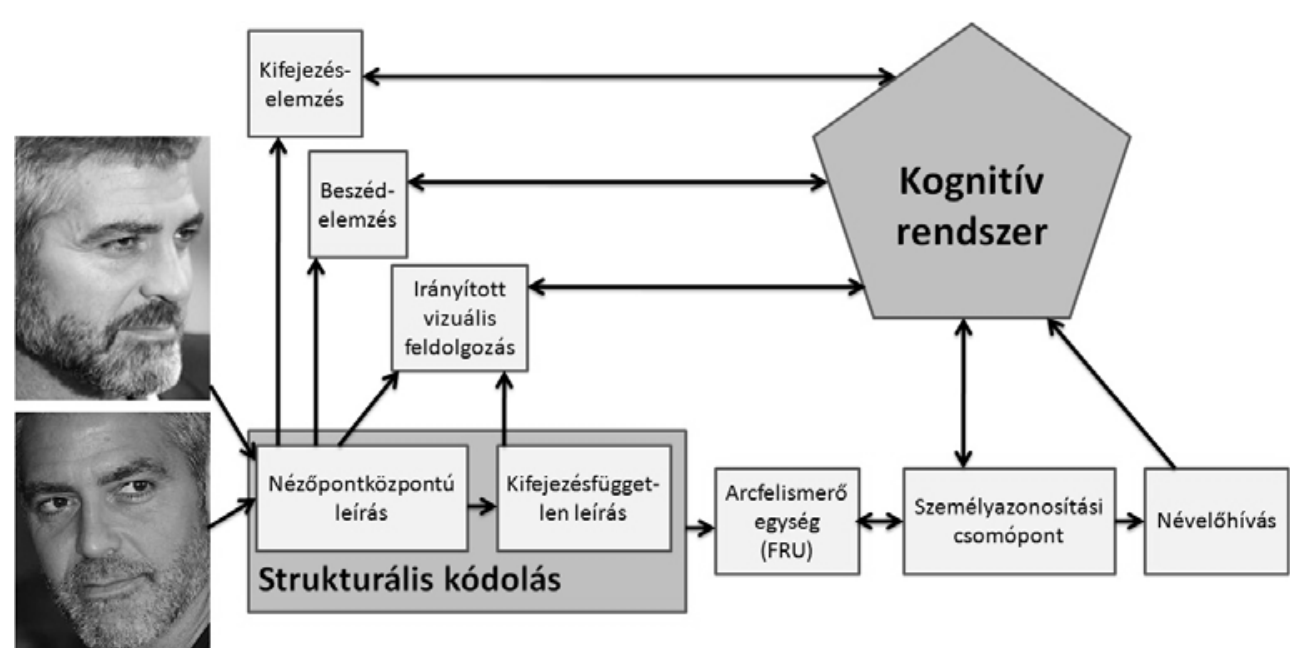

1. ábra. BRUCE és YOUNG 1986-os modellje az arcfelismerés folyamatairól 
zentáció jön létre. A modell szerint amennyiben az arc számunkra ismerős, akkor következik egy mélyebb feldolgozás, amely már független a nézőponttól. Ekkor először aktiválódik az ún. arcfelismerő egység, amely még csak vizuális információt dolgoz fel, de később más modalitásokból származó információ is aktiválódik a felismerési folyamat során. Ehhez kapcsolódnak egyéb általunk ismert szemantikus információk is (honnan ismerem, szimpatikus-e), illetve meg tudom nevezni az illetőt. A folyamat tehát a következő: az arcfelismerő egység továbbítja az információt a személyazonositási csomóponthoz, ami közvetlenül és a kognitív rendszeren át közvetve is lehetővé teszi (amennyiben ismerős arcról van szó) az archoz kapcsolódó információk (név, személyes kötődés, érzelmi tartalmak stb.) elérését. A feldolgozás kezdeti, strukturális szakasza tehát érzékeny például a látott arc látószögére, az arc konfigurációjára, illetve a tekintetirányra.

EEG-vel (a fejbőrre helyezett elektródák segítségével nem invazív módon elvezethető a neurális aktivitás akár ezred másodperces pontossággal; a technikáról magyarul részletesen lásd KÉRI és GULYÁs, 2003a), valamint MEG-gel (idői felbontás, és a mért neurális folyamatokat tekintetve is az EEG-hez hasonló technika (lásd HÄMÄLÄINEN, HARI, ILMONIEMI, KNUUTILA és LOUNASMAA, 1993; magyarul lásd KÉRI és GULYÁs, 2003a) végzett eseményhez kötött kiváltott potenciál (EKP) vizsgálatok tanúsága szerint az arc strukturális kódolása az inger megjelenését követően kb. 170 ms-mal (a 130-200 ms-os idői ablakban) megtörténik. Ezt a negatív polaritású kiváltott választ nevezik N170-nek (MEG-vizsgálatokban a komponens megfelelője az M170) (például Bentin, Allison, Puce, Perez és McCARThy, 1996; GAO és mtsai, 2013; ITIER és TAYLOR, 2004; áttekintésekért lásd EIMER, 2011; Rossion és JACQUes, 2011; SCHWEINBERGER, 2011), amely az occipitotemporalis elektródákon éri el amplitúdómaximumát, de a jobb oldalon - legalábbis arcok esetén - kifejezettebb (ROSSION és JACQUES, 2011). Az arcok által kiváltott N/M170 nem arcszerủ ingerekhez képest nagyobb amplitúdójú (a válasz erőssége) és amplitúdómaximumát általában korábban éri el. Ismertek azonban vizsgálatok, amelyek izolált szempáringerek esetén is a teljes arcok által kiváltotthoz hasonló (sőt amplitúdóban még sokszor nagyobb) N170-et mértek (BENTIN és mtsai, 1996; Itier, Alain, Sedore és MCIntosh, 2007; Itier és BATty, 2009). Többen is úgy gondolják (ITIER és mtsai, 2007; ITIER és BATTY, 2009; KLOTH, ITIER és SCHWEINBERGER, 2013), hogy az amplitúdónövekedés egy lehetséges magyarázata, hogy a szemspecifikus neuroncsoportok (a felfordítás miatt széteső konfiguráció hiányában) felszabadulnak a gátlás alól, és hozzájárulnak az N170 generálásához (PERRETT és mtsai, 1985). Az arcok egyedi, nem-arc ingerektől eltérő feldolgozási módjára (konfigurális feldolgozás) utal az ún. arc-felfordítási hatás is, miszerint ha például fejjel lefelé fordított arc alapján kell felismernünk valakit, nehezebben és pontatlanabbul döntünk, és maga a döntés is hosszabb ideig tart, mint normál állású arcok esetén (YIN, 1969). Ez a hatás azonban sokkal kevésbé igaz tárgyak esetén (például DiAmOND és CAREY, 1986; VALENTINe és BRUCE, 1986). A felfordítási hatás nemcsak viselkedésesen, hanem az EKP-jelekben is megmutatkozik. A felfordított arcok feldolgozása közben elvezetett N/M170 komponens latenciája és amplitúdója megnő a normál állású arcokhoz viszonyítva (lásd például EIMER, 2000a; Rossion és mtsai, 2000). Az, hogy az N/M170 érzé- 
keny az arc-inger felfordítására, további bizonyíték amellett, hogy a komponens a konfigurális feldolgozási folyamatokat tükrözi (BENTIN és mtsai, 1996; EIMER, 2000a; Rossion és mtsai, 2000). Noha az N170 arcfelfordítási hatás eredete nem teljesen tisztázott, újabb, ún. forráslokalizációs technikákat (ezek EKP-felvételeket kiegészítő analízisek (például sLORETA [PASCUAL-MARQUI, 2002], VARETA [FERNÁNDEZ-BOUZAS és mtsai, 2000] stb.) alkalmazó vizsgálatok eredményei szerint az egyenes és a fordított állású arcok feldolgozása is ugyanazokhoz a kérgi területekhez köthető (ITIER és TAYLOR, 2004b; WATANabe, KAKigi és PUCE, 2003).

A szakirodalomban túlsúlyban vannak azok az eredmények, amelyek szerint a strukturális kódolás időablakában még nem tükröződnek az arcfeldolgozás felismerési folyamatai (az előbb ismertetett Bruce-Young-modell azon egységei, amelyek a mélyebb feldolgozást végzik), ezek csak később, 400-600 ms-mal az inger bemutatása után lépnek múködésbe (lásd például N400, P600f; Bentin és DeOuelL, 2000; HENSON és mtsai, 2003). Ezekben a vizsgálatokban az ismerős és ismeretlen arcok esetén mérhető N170 amplitúdója nem különbözött egymástól (lásd például Bentin és Deouell, 2000; Eimer, 2000b; Schweinberger, Pickering, JENTZSCH, BuRTON és KAUfMAnN, 2002), ami arra utal, hogy a feldolgozás e szakaszában még nem aktívak a felismerési folyamatok. Számos ellentétes eredmény is ismert azonban (például CAHAREL, Fiori, BERnARD, LALONDE és REBAI, 2006; CAHAREL és mtsai, 2002; DAI és mtsai, 2014; KLOTH és mtsai, 2006). Több magyarázat is lehet arra, hogy egyes vizsgálatok már ilyen korán, az N170 által tükrözött neurális folyamatok szintjén találnak különbséget. Az egyik elképzelés szerint az ismerős arcok vizuális kódolása egy specifikusabb idegi hálózatban történik, mint az ismeretleneké, és így robosztusabb reprezentációt eredményez (TONG és NAKAYAMA, 1999). Számos, $f$ MRI-vel (a technikáról részletesen lásd GulYás, 2003; GUlYÁs és MÓROCZ, 2008; KÉRI és GUlYÁs, 2003b) végzett vizsgálatban a jobb occipito-temporalis területek csökkent aktivitását mutatták ki a feladat előtt tanult - de szemantikus emlékekkel nem kapcsolódó - arcok esetén korábban soha nem látott arcokhoz képest (M. I. GOBBINI és HAXBY, 2006; KosAKA és mtsai, 2003; Rossion, Schiltz és Crommelinck, 2003; Rossion, Schiltz, Robaye, Pirenne és Crommelinck, 2001), azonban több eredmény is arra utal, hogy a vizuális ismerősség mellett az identitással kapcsolatos információk is modulálják ezen területek aktivitását (például Rotshtein, Henson, Treves, Driver és DOLAN, 2005). Ezeknek a hatásoknak a hátterében az ún. ritka kódolási (sparse coding - a tanulás/gyakorlás hatására egyre specifikusabb neuronpopulációkat aktivál) mechanizmus, vagy pedig az ismerősség hatására csökkent figyelmi igény állhat (lásd Fox, IARIA és BARTON, 2008; M. I. GOBbini és HaXBY, 2006). Az N170 által tükrözött neurális folyamatokat tehát ún. fentről-le (top-down) hatások (például korábbi ismertség, a már eltárolt reprezentációk újraaktiválódása stb.) is modulálják (ROSSION és JACQUES, 2011).

Előzőeken kívül az N170 számos egyéb, az arcingereken végrehajtott változtatásra is érzékeny, például az arcingerhez adott vizuális zaj csökkenti az amplitúdóját (például BANKÓ, GÁL, KÖRTVÉLYES, KOVÁCS és VIDNYÁNSZKY, 2011; JEMEL és mtsai, 2003; Rousselet, Husk, Bennett és Sekuler, 2007, 2008; Rousselet, Pernet, Bennett és SeKuler, 2008), amelyek az előzőekkel együtt mind arra 


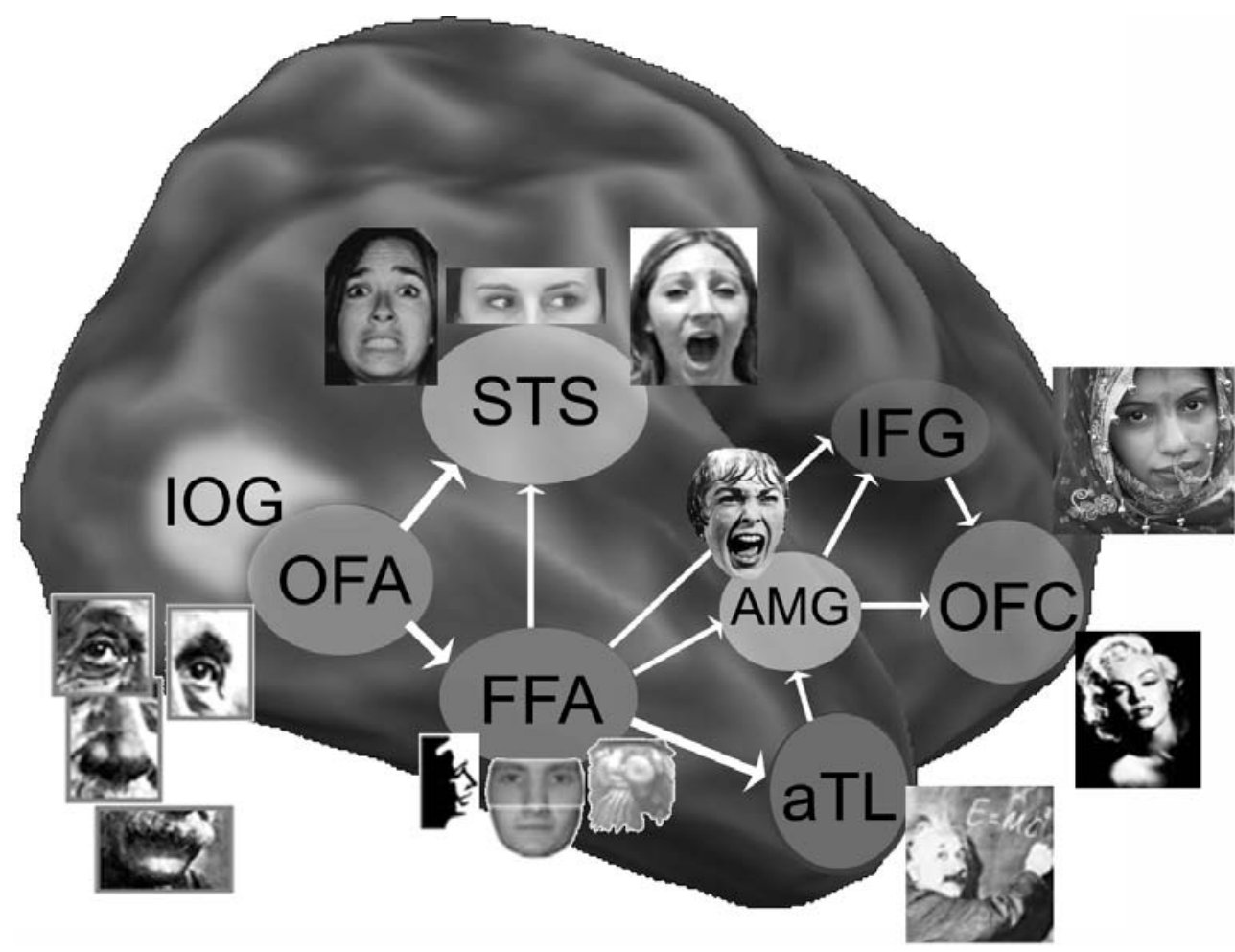

2. ábra. HAXBY és munkatársai (2000) neurokognitív arcfelismerési modellje. IOG-STS-FFA alkotják a magot, a többi pedig a kiterjesztett részhez tartozik.

IOG - gyrus occipitalis inferior; STS - sulcus temporalis superior ; FFA - fusiformis arc terület; a TL - temporalis lebeny elülső területe; AMG - amygdala; IFG - inferior frontalis gyrus;

OFC - orbitofrontalis kéreg

utalnak, hogy ez a komponens inkább a vizuálisinger-kategorizáció perceptuális folyamatait tükrözi, nem pedig magukat a felismerési funkciókat.

Fontos azonban kiemelni, hogy a Bruce-Young-modell csak közvetve kapcsolja össze az egyes funkciókat az idegi működésekkel. E hiány pótlására HAXBY, HOFFMAN és GOBBINI (2000) kidolgozták az arcészlelés/arcfelismerés neurokognitív modelljét, amelynek két fö egysége a mag és a kiterjesztett rendszer (2. ábra). A mag az IOG (arcjegyek elsődleges észlelése), a STS (dinamikus jegyek analízise: tekintet, arckifejezés, szájmozgás) és a lateralis FFA (invariáns tulajdonságok feldolgozása - identitás) együttese.

A kiterjesztett rendszer tagjai a mag területekkel ellentétben sokkal általánosabb, más kognitív funkciókban is érintett fontos idegrendszeri területek. Ezek az agyterületek kulcsszerepet játszanak a magtól kapott információk további feldolgozásában. A kiterjesztett rendszerben az irányított téri figyelemért felelös sulcus intraparietalis, az auditoros kéreg (prelexikus beszédfeldolgozás), valamint az amygdala (érzelmi komponensek) és a temporalis lebeny elülső területe - archoz kapcsol- 
ható név, (ön)életrajzi információk elérése) egyaránt nélkülözhetetlen funkciókkal járulnak hozzá az egészséges arcfelismeréshez (M. I. GobBini és HaXBY, 2007).

Az utóbbi időben azonban egyre több kutatási eredmény is kihívás elé állította az arcfelismerő rendszer magjának neuroanatómiai zártságával és szigorúan előrecsatolt (feed-forward) kapcsolatrendszerével kapcsolatos elméleteket. Egyrészt, a klasszikusan mag területeken kívül, a korábban főleg tárgyészlelésben kulcsszereplőnek gondolt LO (lateralis occipitalis terület [GRILL-SPECTOR, KOURTZI és KANWISHER, 2001]) arcészlelésben betöltött szerepére is találunk bizonyítékokat az irodalomban (például NAGY, GREenLEE és KovACS, 2012). NAGY és munkatársai (2012) funkcionális konnektivitás, vagyis DCM-analízist alkalmazó vizsgálatuk alapján az LO, az OFA (lásd Pitcher, Duchaine, WaLsh, Yovel és Kanwisher, 2011; Pitcher, Walsh és Duchaine, 2011) és az FFA (fusiformis arcterület fusiform face area [lásd KANWISHER, MCDERMOTT és CHUN, 1997; KANWISHER és YOVEL, 2006]) között egy többszörösen összetett - a területek között előre- és hátracsatolt neurális köröket is integráló - modell helyessége mellett érvelnek. Ezzel összhangban egy újabb, $f$ MRI-vel végzett vizsgálat eredményei szerint normál észlelőknél az FFA arcszenzitív válasza időben megelőzi az OFA-ban mért arcszelektivitást (JIANG és mtsai, 2011), ez pedig az OFA és FFA közötti hierarchikusnak feltételezett kapcsolatrendszer elleni további érv. Egy TMS-t (a technikáról részletesen lásd ANTAL, 2003) alkalmazó vizsgálatban az OFA ingerlése az arcfelismerési teljesítményt befolyásolta, míg a kategorizációs folyamatokra nem volt hatással (SOlOMOn-Harris, Mullin és STEEves, 2013), amely hangsúlyozza az OFA fontosságát az arcazonosítási funkciókban, valamint utal az FFA alapvetőbb, kategorizációs folyamatokban betöltött szerepére is. Előbbi bizonyítékok sorába illeszkednek Rossion és munkatársai (2003), valamint STEEves és munkatársai (2006) eredményei is, ahol jobb oldali OFA károsodása ellenére a jobb FFA-ban, illetve STS-ben normális arcszenzitív aktivitást találtak (részletesen lásd lejjebb).

\section{AZ A PROSOPAGNOSIA?}

A prosopagnosia (gr. prosopon $=$ arc; gr. agnosia $=$ nem ismerni; a fogalom első leírója BODAMER volt 1947-ben; lásd később) az ismerős arcok felismerésének zavara, amely normális látási (például látásélesség, színlátás stb.) és emlékezeti funkciók, illetve ép intellektus mellett figyelhető meg. A zavar mértéke egyénileg változó, de minden esetben súlyos, a személy életét megnehezítő probléma.

\section{Előfordulási arány és genetika}

A prosopagnosia iránti egyre fokozódó érdeklődést jól mutatja a cikkek számának óriási emelkedése. Az elmúlt 50 évben a prosopagnosiával foglalkozó cikkek száma a sciencedirect.com keresője szerint évről évre nő, az utóbbi 15 évben pedig ez a szám robbanásszerűen emelkedett. 
Az egyre növekvő számú esetbemutatások és tanulmányok ellenére vannak, akik - ha a prosopagnosia kifejezést kizárólag olyan esetekre alkalmazzuk, ahol semmilyen társult deficit nincs - a zavart extrém ritkának tartják. Azonban ha az arcfelismerési zavart csak egy tünetnek kezeljük a sok egyéb között, amelyek például stroke esetén tapasztalhatók, akkor a zavar sokkal gyakoribb. A vascularis eredetű prosopagnosiás személyek (a zavar kialakulásai leggyakrabban az arteria cerebralis posterior [PCA] területi ellátásának terültén kialakuló keringési zavar; lásd MAYER és Rossion, 2007) aránya a posterior cerebralis laesios betegek között $6 \%$ körüli (HECAEN és ANGELERGUES, 1962).

Újabb, nagy elemszámú mintákon végzett feltáró vizsgálatok eredményei szerint a károsodás hiányában megjelenő prosopagnosia sem olyan ritka, ahogy korábban becsülték. Egy német egyetemen végzett kutatás eredményei szerint a prosopagnosiások aránya a kaukázusi populációban 2,47\% (KENNERKNECHT és mtsai, 2006), míg az ázsiai népcsoportban 1,88\% körüli (GRUETER és mtsai, 2007; Kennerknecht, Ho és Wong, 2008; Kennerknecht, Plumpe, Edwards és RAMAN, 2007). Ezekben a vizsgálatokban az azonosított prosopagnosiás személyek részletes kikérdezésekor többen számoltak be általuk prosopagnosiásnak vélt hozzátartozókról, ami a zavar - legalábbis bizonyos esetekben - örökölhető változatára utal. A prosopagnosia népcsoporttól függetlenül magas, körülbelül $2 \%$ körülire becsült aránya és az egy családban, generációkon keresztül megjelenő arcfelismerési zavar felveti a genetikai eredet kérdését, vagyis hogy a zavar hátterében ugyanaz a génmutáció áll-e az ázsiai és a kaukázusi mintában, illetve ugyanezt találnánk-e afrikai mintán végzett elemzés során. Ha ugyanis etnikumtól függetlenül ugyanaz a génmutáció hozható kapcsolatba a prosopagnosiával, valószínủsíthető lenne egy, még az afrikai kirajzás előtt bekövetkezett génmutáció, míg ha a különböző népcsoportok között más-más gének szerepére találnánk bizonyítékot, az egy újonnan, a nagy vándorlások után bekövetkezett genetikai módosulást valószínüsítene (KENNERKNECHT és mtsai, 2008).

A feltételezhetően örökletes prosopagnosiás esetekről készült beszámolók száma limitált. Egy 2007-es vizsgálatban egy családban 7 testvérnél, mindkét szülőnél és az egyik nagybácsinál - tehát két generációban összesen 10 személynél - is sérült arcfelismerést mutattak ki (B. DUChaine, Germine és NAKAYAMA, 2007). GRUETER és munkatársai (2007) hét család vizsgálatakor 38 prosopagnosiás személyt azonosítottak. LEE és munkatársai (2010) szintén egy családban írták le az apa és két lánya esetét, míg SchMALzL és munkatársai (2008) egy család 3 generációjában számoltak be különböző súlyosságú arcfelismerési zavarral élő személyről. A fenti esetek családfaelemzése alapján megállapítható, hogy az örökletes prosopagnosia autoszomális domináns öröklésmenetűnek tűnik, amelyet egyetlen gén mutációja okozhat (KENNERKNECHT és mtsai, 2006). Olyan esetekben, ahol a kórtörténet a veleszületettséget valószínűsíti, de a családtagok között nincs nyoma a problémának, csupán egy elszigetelt eset jelentkezik, ott újonnan kialakult génmutációt feltételezhetünk. 


\section{Egységes zavar vagy altípusok?}

A neuropszichológia modernkori történetének kezdetén világossá vált, hogy a vizuális deficitek nem kezelhetők egységes tünetegyüttesként, a prosopagnosiáról pedig ismert, hogy neuroanatómiai hátterét tekintve és a károsodás (amennyiben a kiváltó ok agysérülés; az aetiológiáról lásd később) okát illetően, valamint funkcionális szinten sem egységes zavar (SCHWEINBERGER és BURTON, 2003). Ennek ellenére a mai napig sincs egységes, kidolgozott rendszer a zavar osztályozására (KENNERKNECHT és mtsai, 2006), miközben a prosopagnosia altípusokba sorolása nemcsak a tudományos megismerés számára kihívás, vagy a pontos klinikai kép miatt fontos, hanem az esetleges terápiás lehetőségek szempontjából is releváns lenne. A csoportosítás lehetséges szempontjai sokfélék. A következőkben rátérünk a leglényegesebb szempontok részletes tárgyalására.

\section{A prosopagnosia kialakulásának körülményei}

Logikus, ha a zavar osztályozását a kialakulás okainak áttekintésével kezdjük. Erre vonatkozóan az irodalomban három fó típussal találkozunk: a prosopagnosia lehet szerzett (acquired; AP), fejlödési (developmental; DP) és veleszületett (congenital; $C P$ ).

A szerzett prosopagnosia jól azonosítható eseményt követően, amely legtöbbször agyi érbetegség, fejsérülés, az occipito-temporalis területek környékén kialakult agykárosodás következtében, hirtelen jelenik meg (BALA és mtsai, 2014; BUSIGNY, Graf, Mayer és Rossion, 2010; Busigny és Rossion, 2010; DAMasio, Damasio és VAN Hoesen, 1982; Hecaen és ANGElergues, 1962; Meadows, 1974; RAMON, Busigny és Rossion, 2010; Rossion, 2008; Rossion, Dricot, GOEbel és Busigny, 2011; SCHILTZ és mtsai, 2006). Érdekes módon azonban számos, az irodalomban ismertetett prosopagnosiás esetben megfigyelhetők egyéb vizuális deficitek (például J. J. BARTON, Cherkasova, Press, InTriligator és ConnOR, 2003), vagy arcokon kívül más ingerkategórián belüli felismerési zavarok (például DE HAAN és CAMPBELL, 1991). Ez adódik egyrészt a károsodás helyének változatos jellegéből, másrészt az arcfelismerés folyamataiban részt vevő területek kis méretéből, illetve abból, hogy e területek más funkciókhoz köthető agyterületek közvetlen szomszédságában helyezkednek el. Mindezek megnehezítik az irodalmi adatok helyes értelmezését, mivel sok esetben ez a változatos tünetcsoport a nem megfelelően kiválasztott esetekből, illetve a vizsgálatok nem szakszerű kontrollálásából adódik.

Időrendileg az irodalomban a szerzett zavar jelent meg elsőként, mivel a két világháború számos agysérült beteget eredményezett. A szerzett zavarokról számon tartott egyik első beszámoló három katona esetét mutatta be, akik az első világháborúban szenvedtek agykárosodást, amelynek következtében a károsodás kiterjedtségétől függően különböző súlyosságú arcfelismerési zavart és egyéb vizuális deficiteket (például tárgy-agnosia) is mutattak (BODAMER, 1944).

A prosopagnosia másik fó típusa az ún. fejlódési prosopagnosia. Az elnevezés azonban csak egy gyưjtőkifejezésnek tekinthető, a valódi kiváltó okról keveset árul 
el (GRUETER és mtsai, 2007). A fejlődési esetekben ugyan nincs dokumentált agykárosodás az élettörténetben, általában az intelligencia a normál tartományba esik, és nem mutatható ki zavar az alacsony szintű vizuális képességekben (BEHRMANN és Avidan, 2005; B. C. Duchaine, 2000; B. C. Duchaine és Nakayama, 2006b; Kress és Daum, 2003; Palermo, Rivolta, Wilson és JefFery, 2011; Rivolta, Palermo, Schmalzl és Coltheart, 2012; Rivolta, Palermo, Schmalzl és Williams, 2012; Rivolta, Schmalzl, Coltheart és Palermo, 2010). Kétséget kizáró bizonyíték azonban nincs arra, hogy a tünetek nem például születés előtti, illetve körül komplikációkhoz (például oxigénhiányos állapot) köthetőek, ami rejtve maradhat a kórtörténetben (KENNERKNECHT és mtsai, 2006).

Abban az esetben, amikor a fent említett agyi károsodások, születéskor bekövetkező komplikációk egyértelműen kizárhatók, de az illetőnek mégis nehézségei vannak az általa ismert személyek felismerésében, akkor beszélhetünk veleszületett prosopagnosiáról (DOBel, Bolte, Aicher és SCHWEInberger, 2007; Dobel, Junghofer és Gruber, 2011; Dobel, Putsche, Zwitserlood és Junghofer, 2008; Palermo, Willis, és mtsai, 2011; Rivolta, Palermo és Schmalzl, 2013; Rivolta, Palermo, Schmalzl és Coltheart, 2012; Rivolta, Palermo, Schmalzl és Williams, 2012; Rivolta és mtsai, 2010; Schmalzl, Palermo, Green, Brunsdon és Coltheart, 2008; Stollhoff, Jost, Elze és KennerKNECHT, 2010; C. THOMAS és mtsai, 2009). Ilyen esetekben nagy bizonyossággal megállapítható - többnyire a szülői beszámolók alapján -, hogy a zavar kora gyerekkortól fogva jelen van, és a probléma megjelenése nem köthető semmilyen központi idegrendszert érintő elváltozáshoz. Ismert, hogy a csecsemők a születést követően szinte azonnal érdeklődnek az arcszerű konfigurációval rendelkező ingerek iránt (MORTON és JOHSON, 1991), így vannak, akik a veleszületett típus hátterében ennek a vélhetően veleszületett arcpreferenciának a sérülését valószínűsítik. Tekintve, hogy a zavar születéstől fogva megfigyelhető, ezekben az esetekben sem zárható ki az örökletes tényezők szerepe (DE GELDER és STEKELENBURG, 2005). Genetikai vizsgálat hiányában az örökletes (hereditary) prosopagnosia azonban csak azokban az esetekben helytálló elnevezés (noha sokszor a veleszületett szinonimájaként használják), ha a vérszerinti rokonok között is találunk arcfelismerési zavarral élő személyt (KENNERKNECHT és mtsai, 2006). A zavar genetikai hátterével kapcsolatban tényleges vizsgálat a mai napig nem történt, így az öröklésmenetre csak az egy családban, generációkon át megjelenő prosopagnosia előfordulási mintázata alapján következtethetünk. Egyelőre kevés családi halmozódást bemutató tanulmány ismert (B. Duchaine és mtsai, 2007; GRUETER és mtsai, 2007; KENNERKNECHT és mtsai, 2006; KENNERKNECHT és mtsai, 2008; KENNERKNECHT és mtsai, 2007; LEe és mtsai, 2010; NéMETH és mtsai, 2015; NÉMETH, ZiMMER, Schweinberger, Vakli és Kovács, 2014; Schmalzl, Palermo és Coltheart, 2008; SCHWARZER és mtsai, 2007).

A kialakulás szerinti csoportosítás tehát sok tekintetben informatív, de a zavar egyéb aspektusaival kapcsolatban - például az agyban lévő strukturális, valamint funkcionális eltérésekkel -, nem ad fogódzót, így a következőkben ezeket tekintjük át. 
A szerzett prosopagnosiás esetekben a tünetet okozó károsodások területileg igen változóak. Ami a kétoldali aszimmetriát illeti, eddig mindössze néhány esetben írtak le kizárólag bal oldali károsodást követően prosopagnosiát (például EIMER és MCCARTHy, 1999; MatTSON, LeVIN és GRAFMAN, 2000), minden egyéb esetben jobb oldali, illetve bilaterális érintettség volt tapasztalható (áttekintésért lásd Bouvier és Engel, 2006; Fox és mtsai, 2008; GaINOTTI és MARra, 2011). Ezek az eredmények újfent kiemelik a jobb félteke domináns szerepét az arcfeldolgozás neurális reprezentációjában (lásd MAYER és Rossion, 2007). A jobb IOG és az FFG medialis része azok a területek, ahol a legtöbb szerzett prosopagnosiásnál található károsodás (lásd Busigny, Joubert, Felician, CecCAldi és Rossion, 2010; TOWLER és EIMER, 2012). Ez illeszkedik a korábban már ismertetett arcfelismerési modellek által leírtakhoz, hiszen ezekhez az agyterületekhez köthetők az identitás feldolgozásának alapvető perceptuális folyamatai (M. I. GOBBINI és HaXby, 2007; HaXby és mtsai, 2000; HaXby, Hoffman és Gobbini, 2002; LiU, HARRIS és KANWISHER, 2010). Az FFA mellett az OFA arcészlelésben betöltött kritikus szerepére utal egy jól ismert beteggel (PS) végzett számos vizsgálati eredmény is (Rossion, CALDARA, és mtsai, 2003; STEEves és mtsai, 2006). PS-nek a bal oldalon az FFA, míg a jobb oldalon az OFA területére kiterjedő agykárosodása keletkezett egy zárt koponyasérüléssel járó baleset következtében. PS jobb oldali FFA-ja normális működést mutatott az OFA kiterjedt károsodása mellett, ennek ellenére súlyos prosopagnosiás tüneteket mutat a mai napig. A PS-től származó eredmények alapján Rossion és munkatársai (2003) úgy vélik, az arc alapján történő személyazonosítás zavara a jobb FFA-ból OFA-ba visszacsatoló neurális folyamatok sérülésére is visszavezethető, ami illeszkedik a mag területek közötti előrecsatolt viszonyokat megkérdőjelező eredmények sorába (lásd korábban).

A fejlődési prosopagnosiás tanulmányok egyik legtipikusabb kezdőmondata szerint a „fejlődési prosopagnosia az arcfelismerés zavara nyilvánvaló agykárosodás nélkül”. Jó néhány vizsgálatban azonban a veleszületett prosopagnosiás személyeknél is kimutattak strukturális eltéréseket, bár tény, hogy klasszikus értelemben ezek nem tekinthetők károsodásnak. BEHRMANN és AVIDAN (2005) a jobb temporalis lebeny és a jobb FFG anterior részének csökkent térfogatát mérték, míg egy 2007-es vizsgálatban hat, születésüktől prosopagnosiás személynél szintén kimutatták a FFG anterior részének térfogatcsökkenését. A prosopagnosiás személyeknél a csökkenés mértékének függvényében romlott az arcfelismerési teljesítmény, míg ez az összefüggés nem volt igaz a kontrollszemélyek esetén (BEHRMANN, AVIDAN, GAO és BLACK, 2007). Tovább árnyalja a képet, hogy nemcsak szerzett, hanem veleszületett prosopagnosiás személyeknél is megfigyeltek a mag területek kóros működésén, illetve a fent felsorolt strukturális elváltozásokon kívül e területek közötti fehérállományi abnormalitásokat is (például az adott pályarendszer kevésbé sűrű, kisebb a térfogata). AVIDAN és BEHRMANN (2009), valamint THOMAS és munkatársai (2009) a ventralis occipito-temporalis kéreg temporalis lebeny anterior részébe, valamint a frontalis lebenybe futó pályáinak strukturális eltéréseit írták le, amelynek egyik oka a szerzők szerint lehet egy abnormális gén- 
expresszió, ami az agy fejlődésének kritikus periódusában zavart idéz elő a mag területeket összekötő pályarendszerek érésében. A fehérállomány érintettségével kapcsolatos eredményeket nem sikerült azonban reprodukálnia DinKELACKERnek és munkatársainak (2011), ahol a nagy elemszámú (24 CP - 25 kontroll) prosopagnosiás csoport átlagos szürke- és fehérállományi sűrűségben nem különbözött a kontrollcsoporttól.

A képalkotó eljárásokkal nyert eredmények tehát szintén nagyfokú heterogenitást mutatnak, ezek alapján a fejlődési prosopagnosia - szemben a szerzett zavarokkal, ahol a deficit könnyebben összeköthető egy/több agyterület károsodásával (TOWLER és EIMER, 2012) - sokkal inkább tűnik egy hálózati zavarnak, ahol akár egyszerre lehet érintett a mag és a kiterjesztett rendszer.

\section{A prosopagnosia lehetséges csoportositása funkcionális jellemzők szerint}

$\mathrm{Az}$ arcspecifikus neurális folyamatok megléte gyakran és sokat hangoztatott érv arra, hogy az idegrendszer ezeket a kategóriákat különböző módon/helyen dolgozza fel. Talán ennek az erős elkülönítési akaratnak köszönhető, hogy csak ritkán merül fel a kérdés, vajon a tárgyészlelési zavarok (agnosia) csoportosítása során használt alcsoportokat az arcfelismerési zavarra is alkalmazhatjuk-e. Közismert vélemény szerint a prosopagnosia az ún. „kategória-specifikus” agnosiák egy típusa (WURTZ és KANDEL, 2000).

A tárgyfelismerési zavarokat LISSAUER (1890) bontotta apperceptív és asszociatív formákra. Míg az apperceptív típus esetén a tárgyfelismerési zavar hátterében a korai vizuális-perceptuális folyamatok sérülése áll, addig az asszociatív zavarnál a tárgyakkal kapcsolatos szemantikus reprezentációk (név, használat módja stb.) elérése nehezített. Lissauer után mintegy egy évszázaddal Arthur BENTON (1984) a prosopagnosiával kapcsolatban is felveti a zavar ily módon való altípusokra bontását a különböző szintű feldolgozási folyamatok épségétől függően. Ezt követően a Lissauer által javasolt osztályozás analógiájára DE RENZI, FAGLIONI, Grossi és NiCHELLI (1991) a prosopagnosia esetén is helytállónak tartották az apperceptív (prosopagnosia) és az asszociatív (prosopamnesia) altípusok elkülönítését, illetve kiemelték a differenciálás klinikai hasznosságát. Bár újabban a szerzett zavarral kapcsolatban Jason Barton felveti az apperceptív/asszociatív felosztás lehetőségét (J. J. Barton és mtsai, 2003; Davies-Thompson, Pancaroglu és Barton, 2014; Fox és mtsai, 2008), az elmúlt több mint 20 évben mindezen elképzelések - érthetetlenül - feledésbe merültek, és ez a szemléletmód ritkán köszön vissza az azóta lefolytatott prosopagnosiás vizsgálatokban.

Noha például a veleszületett és fejlődési prosopagnosia neurális hátterére vonatkozó eredmények diverzitása indokolná, érdekes módon mindmáig kevésbé merült fel az altípusokra bontás lehetősége. Duchaine és NAKAYAMa (2006a) szerint az irodalmi adatokat ismerve ilyen fokú heterogenitás mellett azonban nem lenne haszontalan a fejlődési prosopagnosia alcsoportokra bontása. Több kutatócsoport - köztük mi is - ugyanerre az álláspontra jutott (lásd például SCHMALZL, 
Palermo és Coltheart, 2008), de az alcsoportokra vonatkozó kérdések tisztázása lehetetlen nagyobb mintán készült vizsgálatok nélkül, ahol ugyanazokkal a személyekkel széles körủ neuropszichológiai tesztsorozatból és elektrofiziológiai, valamint képalkotó eljárásokkal végzett kísérletekből származó információk is rendelkezésre állnak. A pár tucatnyi, irodalomban ismertetett esetből csak indirekt következtetésekre juthatunk, amelyek tudományos helytállóságát nagyban nehezítik a különböző vizsgálatok közötti módszertani különbségek. Valódi nagymintás, empirikus vizsgálat nélkül az esetleges alcsoportok pontos természetéről csak spekulálni lehet, az eddig említett vizsgálatok konklúziója sem lehet több mint, hogy a veleszületett zavar kognitív profilja változatos.

Saját vizsgálataink során - eddig egyedülállóan - egy család három érintett tagjával (apa és két gyermeke) és hozzájuk illesztett kontrollszemélyekkel a neuropszichológiai tesztelés mellett EKP- és $f$ MRI-vizsgálatokat is végeztünk (NÉMETH és mtsai, 2015; NÉMETH, ZIMMER és mtsai, 2014), továbbá egy jelen pillanatban 35 fős prosopagnosiás minta és hozzájuk illesztett kontrollcsoport tesztelését végeztük el öt különböző EKP-paradigmával, valamint számos neuropszichológiai vizsgálóeljárás alkalmazásával.

\section{Mennyiségi vagy minőségi különbségek?}

Ahogy számos idegrendszeri probléma, a prosopagnosia esetén is felvetődik, vajon nem egy spektrumzavarral van-e dolgunk? Más szavakkal, az egészséges felismerők és a prosopagnosiás személyek diszkrét vagy pedig folytonos kategóriát képeznek a felismerési teljesítmény és a neurális háttérmechanizmusok tekintetében?

A prosopagnosiára szokás egy különleges „kulcslyukként” tekinteni, amin át bepillanthatunk az arcfelismerés idegrendszeri szerveződésébe, a veleszületett zavar megismerésétől pedig az arcfelismerés agyi hálózatrendszerének genetikai feltérképezését remélik. Vannak azonban, akik szkeptikusak a sérültekből, illetve a nem tipikusan müködő agyból nyert adatok általánosíthatóságával kapcsolatban. A gyakran egészséges személyektől gyüjtött adatok alapján felállított, erősen modularista felfogású modellek, vizsgálati és terápiás módszerek, neuropszichológiai elvek helyességét sok esetben igazolni látszanak az agysérült személyektől gyűjtött eredmények. Többen vitatják azonban, hogy ezek megállják-e a helyüket egy eleve atipikusan fejlődött idegrendszer vizsgálata esetén (lásd TOWLER és EIMER, 2012). Az idegrendszer egészét illetően (beleértve természetesen a vizuális feldolgozás neurális szerveződését is) felmerül tehát a kérdés, hogy ha az agy fejlődése az ontogenezis kezdetétől egyfajta kényszerpályán történik, akkor a kifejlődött rendszer szerveződhet-e az arcfelismerés szempontjából egészséges populáció vizsgálatával nyert modelleknek megfelelően. Más szavakkal, kérdés, hogy az eleve eltérő módon fejődött idegi hálózatok „,csak” mennyiségileg csökkent viselkedéses teljesítményhez vezetnek, vagy az arcfelismerő rendszer működésmódjában is eltéró, minőségi különbséget mutat a normális működésűhöz képest (KARMILOFFSMITH, 2009; TOWLER és EIMER, 2012). Számos példa mutatja ugyanis, hogy akár normál teljesítmény mögött is találhatunk eltérően funkcionáló idegi hálózatokat. 
A Williams-szindrómások például súlyos nyelvi, mozgáskoordinációs és figyelmi problémáik ellenére viselkedéses arcfelismerési teszteken gyakran az egészséges arcfelismerőkével egyforma eredményt érnek el. Fontos azonban megjegyezni, hogy éppúgy találunk irodalmi bizonyítékot kiemelkedő, átlagos, sőt jelentősen rossz arcfelismerési teljesítményükről is. A ritka, genetikai eredetű zavarnak számos, belgyógyászati, izom- és vázrendszeri, valamint a felsoroltakon túl további idegrendszeri tünete is van, amelyek tárgyalása túlmutat jelen tanulmány célkitủzésein. A normális arcfelismerési teljesítmény ellenére kimutatható, hogy kevésbé érzékenyek az arc konfigurációjának megváltozására és a felfordítási hatás is eltér az egészségeseknél tapasztaltaktól (Deruelle, Mancini, Livet, CASSE-PERrot és DE SCHONEN, 1999). Ennek azonban elsősorban nem speciálisan az arcok feldolgozásának károsodása áll a hátterében, hanem általánosan egy lokális jellegű ingerfeldolgozás a globális, egészleges feldolgozással szemben. Mindezek mellett az egyenes állású arcok feldolgozása is minőségi különbséget mutat normális fejlődésű személyekkel összehasonlítva: a Williams-szindrómások csökkent gamma(32-48 Hz) aktivitása egyenes állású arcok esetén a binding (a bejövő információk koherens egésszé integrálása [lásd SINGER, 2001]) problémájára utalhat (GRICE és mtsai, 2001). Egy friss vizsgálatban szintén a gamma-aktivitás csökkenését mutatták ki a bal FFA-ban veleszületett prosopagnosiások esetén az inger bemutatását követő 170-350 ms-os időablakban (DOBEL és mtsai, 2011). DoBEL és munkatársai (2011) szerint a bal oldalon talált eltérés egyik oka az lehet, hogy a prosopagnosiások a holisztikus arcfelismerési folyamatok sérülésének kompenzálására inkább az ún. jegyillesztési stratégiát (BEHRMANN és AVIDAN, 2005) használják, ami a konfigurális feldolgozásért felelős területek alacsonyabb aktivációjával járhat. A jegyillesztés során az arcon található arcrészletek (jegyek: szem, orr, száj, szemöldök, anyajegyek stb.) perceptuális analízise és egyeztetése egy másik arc jegyeivel egyesével történik és nem egészlegesen, a jegyek integrációjával. Ha az illetőnek meg kell állapítania két arcról, hogy egyformák-e, vagy sem, azt úgy végzi, hogy összehasonlítja, hogy a szem formája vagy egy jellegzetes bőrhiba, apró forradás megtalálható-e a másikon is, vagy sem.

\section{A PROSOPAGNOSIA LEHETSÉGES ALTÍPUSAI ÉS AZ ARCFELISMERÉSSEL ÖSSZEFÜGGŐ ZAVAROK HELYE AZ ARC- FELISMERÉS NEUROPSZICHOLÓGIAI MODELLJEIBEN}

BRUCE és YOUNG (1986) módosított modelljében az arcfelismerő egység a ventralis temporalis struktúrák, például FFA, működéséhez köthető (3. ábra; lásd SCHWEINBERGER és BURTON, 2003). A modell szerint önálló úton, külön idegrendszeri struktúrák segítségével valósul meg a személyfelismerés és az arcokhoz köthető érzelmi válaszgenerálás. Ha feltételezzük a prosopagnosia esetén is az apperceptív/asszociatív felosztás helyességét, akkor az apperceptív típus esetén a strukturális kódolás szintjén vagy a strukturális kódolás és az arcfelismeró egység közötti kapcsolatrendszerben (1-es jel a 3. ábrán), esetleg magában az arcfelismerö egység működésében találnánk problémát. Az ilyen típusú zavarral élők egy olyan teszten is gyenge 
teljesítményt mutatnak, ahol két, egyszerre látható arcról kell eldönteni, hogy azonosak-e (vagyis a feladatnak nincs emlékezeti komponense), vagy ha például több arcrészlet közül (például 3 szempár, vagy 3 fül stb.) kell kiválasztani, hogy melyik tartozik a részletekkel egy időben látható archoz. Több ilyen eset ismert az irodalomban, például JL és CM (Towler, Gosling, DuCHAINe és EIMER, 2012), LL és MG (Rivolta, Palermo, Schmalzl és Williams, 2012), f35, f38f, f39, f30, m33 (B. DuChaine és mtsai, 2007), de sosem vizsgálták ezeket az eseteket külön azoktól, akik a perceptuális arcteszteken normális teljesítményt értek el. Számos arcteszt létezik, ahol emlékezeti komponens nélkül, az arcfeldolgozás perceptuális szakaszait lehet tesztelni (például PFPB - Philadephia Face Perception Battery [A. L. Thomas, Lawler, Olson és Aguirre, 2008]; vagy a CFPT - Cambridge Face Perception Test [B. DuCHAINe és mtsai, 2007]). A CFPT különböző életkorhoz tartozó átlag-, valamint szórásértékei egy nagymintás vizsgálatnak köszönhetően ismertek is (lásd BowLEs és mtsai, 2009).

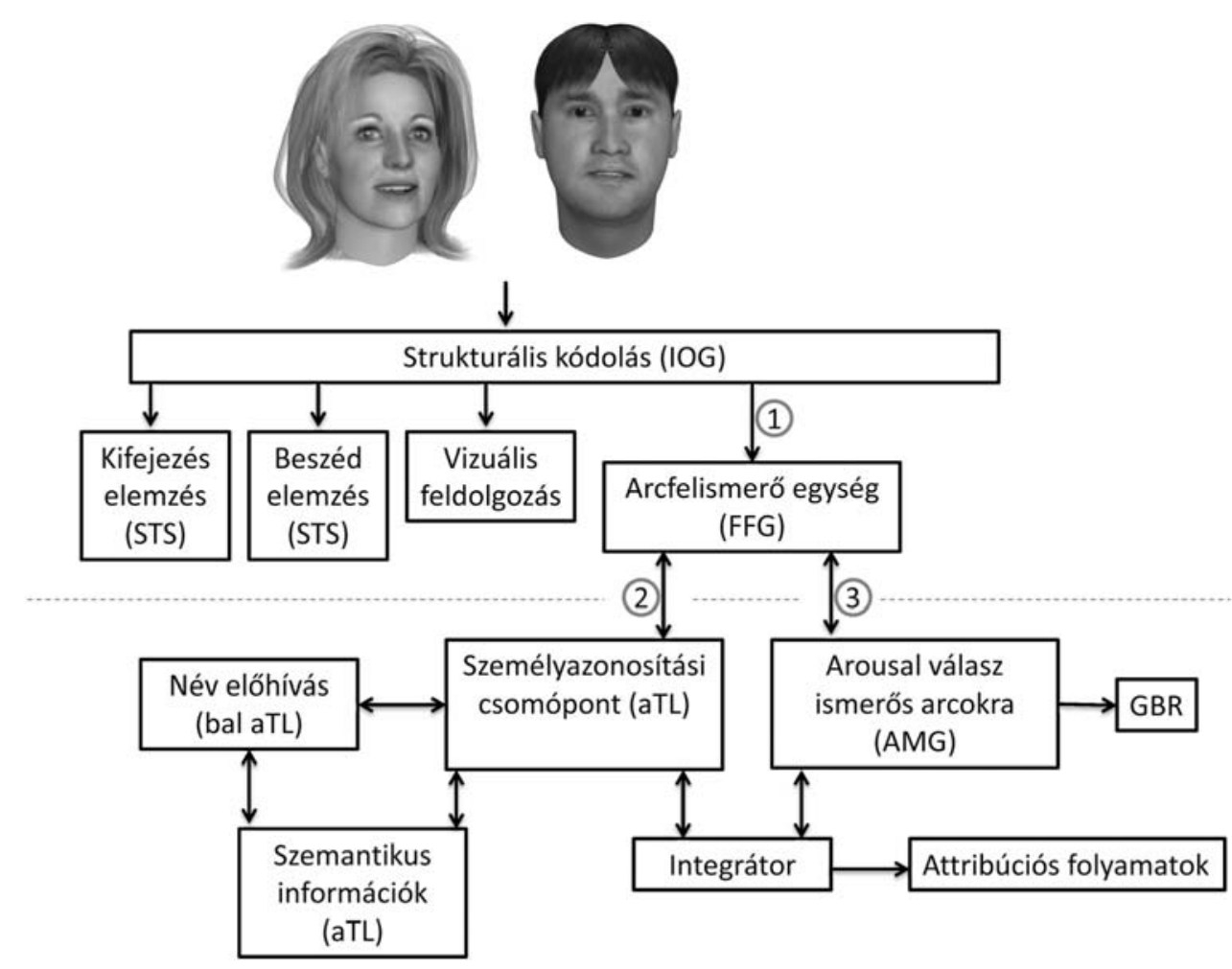

3. ábra. Az arcfelismerés kiegészített modellje BURTON és munkatársai (1999), BREEN és munkatársai (2000), illetve ELLIS és LEWIS (2001) nyomán

IOG - gyrus occipitalis inferior; STS - sulcus temporalis superior ; FFG - gyrus fusiformis;

aTL - anterior temporalis lebeny; AMG - amygdala; GBR - galvános bőrreakció.

Az arcok a FaceGen Modeller 3.5 (Singular Inversions Inc.) programmal készültek. 
Első lépésként a jövő nagy elemszámú prosopagnosiás vizsgálataiban a gyüjtött idegtudományi adatokat, viselkedéses eredményeket, például a CFPT-n elért pontszám függvényében érdemes lenne megvizsgálni, illetve ahol erre lehetőség van, ott a már meglévő adatok újraelemzése is érdekes eredményeket hozhatna (például TOWLER és mtsai, 2012). TOWLER és munkatársai (2012) vizsgálatában például rendelkezésre áll 32 személy (16 prosopagnosiás, 16 kontroll), akiktől származó elektrofiziológiai mérési adatok és az arcfelismerés perceptuális folyamatait vizsgáló teszteredmények összefüggésének vizsgálatával izgalmas, új eredményekhez juthatnánk az arcfeldolgozás perceptuális és emlékezeti szakaszait illetően. Ha az arcfelismerési folyamatok az arcfelismerő egységig normálisan működnek (szaggatott vonal a 3. ábrán), akkor a további folyamatok és kapcsolatok épségétől függ, találunk-e valamely, az arcok feldolgozásához köthető felismerési/emlékezeti/érzelmi folyamatban problémát. Amennyiben az arcfelismerö egység és a személyazonosítási csomópont között (2-es jel a 3. ábrán) van a probléma, vagy ezt követően bármilyen részfolyamatban, úgy asszociatíu prosopagnosiáról beszélünk (például Case1; Takahashi, Kawamura, Hirayama, Shiota és Isono, 1995). Az arcfelismerési zavar e változata számtalan tünet formájában jelentkezhet. A részfunkciók épségétől függően előfordulhat, hogy például az arc megpillantásakor az ismerősségi érzés megvan ugyan, de az illető semmilyen konkrét szemantikus/epizodikus információt nem tud előhívni (például ME esete, DEHaAn, Young és NEWCOMbe, 1991). Olyan eset is ismert a szakirodalomban, ahol az illető éppen csak az archoz tartozó névhez nem fér hozzá (anomia - szótalálási vagy megnevezési zavar), míg egyéb szemantikus információk felidézése nem okoz problémát (például EST esete; Flude, ElLIS és KAY, 1989; összefoglalásért lásd Fox és mtsai, 2008). Az ilyen típusú problémákkal gyakran találkozhatunk a prosopagnosiások mindennapi beszámolóiban (például KENNERKNECHT és mtsai, 2006).

\section{PROSOPAGNOSIA - A KORAI SZŰRÉS ZAVARA}

Nyilvánvaló, hogy az elmúlt 20 évben az N170 arcszenzitivitása és a felfordítási hatás arcspecifikussága képezte az elektrofiziológiai módszerekkel végzett arcfelismerési vizsgálatok központi kérdését. Ezek alapján pedig azt is láttuk, hogy az N170 időablakában zajló folyamatokat a strukturális kódolási, perceptuális funkciókkal hozzák összefüggésbe. Ismerve a fenti tényeket, és tudva, hogy sokan a prosopagnosia esetén leginkább a strukturális kódolási folyamatok sérülését valószínűsítik, nem meglepő, hogy az EEG/MEG-gel végzett prosopagnosiás vizsgálatok egyik leggyakrabban vizsgált komponense az N/M170. Noha a vizsgálati eredmények nem egybehangzóak, az egyedi esetek áttekintése után mégis felfedezhető a prosopagnosiások egy alcsoportjára jellemző közös tulajdonság. Bizonyos prosopagnosiások N/M170-je megtartja arcszenzitivitását, de több olyan eset is van, akiknél nem találunk különbséget az arc- és a nem-arc ingerek kiváltott válaszainak amplitúdóiban (az ismert esetek erre vonatkozó N/M170 arcszenzitivitás és arcfelfordítási hatás eredménye az 1. táblázatban kerülnek összefoglalásra; lásd a tanulmány végén). A különbség hiánya ritkán vezethető vissza az arc által 
generált válasz amplitúdójának (vagy általánosan az EEG-jelnek) a csökkenésére, a legtöbb ilyen esetben a különbség hiányát a nem-arc ingerek által generált nagy amplitúdójú válasz eredményezi (például BenTin, DEGUTIS, D’Esposito és ROBERTSON, 2007; az ismert esetek összefoglalását részletesen lásd az 1. táblázatban).

Az előbb felsorolt eredmények ellenére egy friss, a fejlődési prosopagnosiás EKP-vizsgálatokat is áttekintő tanulmány szerint a zavar elektrofiziológiai korrelátuma nem az arcszenzitivitás zavarában, hanem sokkal inkább a felfordítási hatás hiányában érhető tetten (TOWLER és EIMER, 2012). TOWLER és EIMER (2012) álláspontja szerint az N170 arcszenzitivitása és bizonyos későbbi kiváltott válaszkomponensek (N250, P600) a legtöbb prosopagnosiásnál is megfigyelhetők, és a kontrollokhoz hasonlóak.

Ellentétben TOWLER és munkatársai (2012) elképzelésével DuCHAINE (2011) szerint bizonyos prosopagnosiás személyeknél a probléma oka egy alacsonyabb szintű, korábbi perceptuális folyamat, a korai szürés zavarára vezethető vissza ezekben az esetekben a nem-arc inger által kiváltott válasz amplitúdóját és skalpeloszlását tekintve az arc által generált kiváltott válaszhoz hasonlít. A pontos neurális háttérmechanizmus kevéssé ismert (de lásd NÉMETH, ZIMMER és mtsai, 2014), ám a jelenség egyik lehetséges magyarázata, hogy a korai látókérgi területek kevésbé feldolgozott, nem szelektált információt továbbítanak a magasabb szintű feldolgozási folyamatokat végző ventralis occipito-temporalis területek felé, ami pedig nem elég szelektíven aktiválja a specifikus területeket (például FFA). Azokban az esetekben, ahol az N/M170 megtartja arcszenzitivitását, a későbbi folyamatok károsodása feltételezhető. A hipotézis tisztázása további vizsgálatokat igényel, de az áttekintett eredmények, saját vizsgálataink tapasztalatai és az arcfelismerés magjával kapcsolatos újabb információk ismeretében a prosopagnosia bizonyos eseteiben felvetődhet a LO működészavara. A LO Nagy és munkatársainak (2012) eredményei szerint közvetlen bemenetül szolgál az OFA és az FFA számára, újabb vizsgálatok pedig kimutatták a LO-aktivitás és az inger feldolgozásához szükséges kapacitásigény közötti szoros kapcsolatot, ha pléldául zajt keverünk egy arcingerhez - megnehezítve ezáltal az arcként való feldolgozást -, az LO nagyobb aktivitást mutat, mint tiszta arcok feldolgozásakor (BANKÓ és mtsai, 2011). Ez összhangban van azokkal az eredményekkel, amelyek az LO tárgyszegmentációs és csoportosítási folyamataiban betöltött szerepére utalnak (GRILLSpector és mtsai, 2001; Kourtzi és Kanwisher, 2001; Lerner, HeNDler, BenBaSHat, HaRel és MALACH, 2001).

Saját vizsgálataink, amelyet egy család három tagjával végeztünk, összhangban vannak a fenti eredményekkel. Az N170 amplitúdói a 100\%-ban randomizált fázisú arcképek (DAKIN, Hess, LEDGEWAY és ACHTMAN, 2002) és zaj nélküli, tiszta arcingerek esetén nem különböztek (NÉMETH, ZIMMER és mtsai, 2014). Továbbá ugyanezen személyek $f$ MRI-vizsgálatakor - ahol szintén arcokat és ezek zajosított változatait alkalmaztuk - az FFA-, az OFA- és az LO-területeken eltérő dinamikájú BOLD-jel (blood oxygen level dependent - véroxigénszint-függő) mellett a mag területek egyike sem mutatott arcingerekre emelkedett aktivitást a prosopagnosiás család tagjainál (NÉMETH és mtsai, 2015). Az LO nem tartozik a forráslokalizációs 


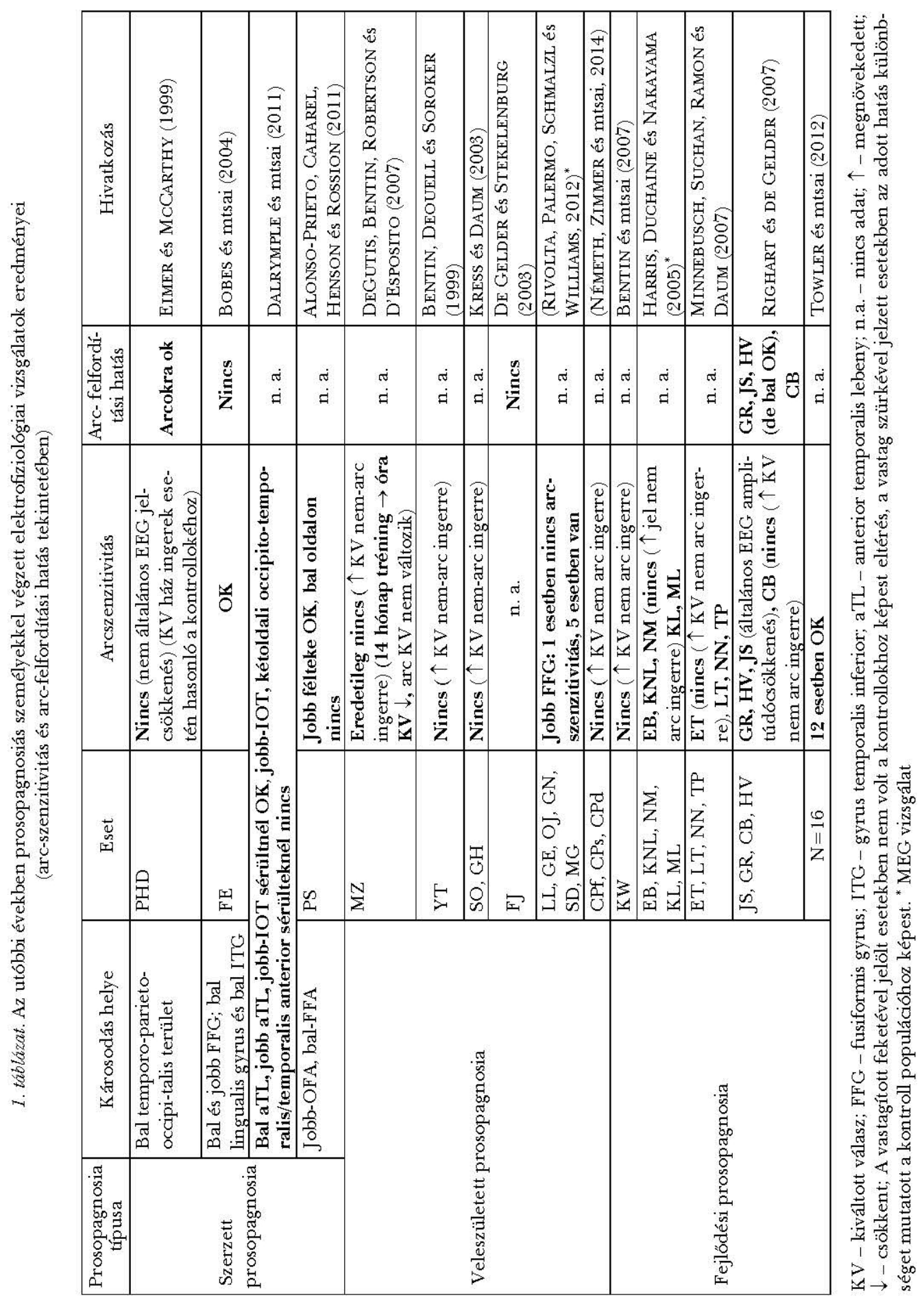


vizsgálatokban klasszikusan az N170 kérgi generátoraként azonosított területek közé (lásd ROSSION és JACQUeS, 2011), ez azonban nem vezet ellentmondáshoz. Ha a korai szűrés hipotézist tovább gondoljuk, és feltételezünk egy kérgi állomást, ahol az ingerek előfeldolgozása történik, a ventralisabban elhelyezkedő területeken mérhető válaszok ennek az állomásnak a működésétől függően alakulhatnak, noha a terület maga - például LO - közvetlenül nem járul hozzá az N170 keletkezéséhez. Az LO szerepe az arc- és tárgyészlelés folyamataiban tehát további vizsgálatokat igényel. Feltételezhetjük azonban, hogy ha az LO - a korábban gondoltakkal ellentétben - kevésbé tárgyspecifikus feldolgozó állomás (lásd például NAGY és mtsai, 2012), és fontos szerepe van az inger releváns jegyeinek a szűrésében például zajfeldolgozásban (lásd például BANKÓ és mtsai, 2011) -, következésképpen tárgyképek zajosításakor ahhoz hasonló aktivitásváltozást várnánk el, amit arcképek zajosításakor is megfigyelhetünk. Saját, egészséges személyekkel végzett idevonatkozó vizsgálataink megerősítik ezt, hiszen arcok és autók által kiváltott N170 amplitúdói azonos mértékủ zajosítás esetén hasonló mértékű - bár arcok esetén valamivel kisebb - csökkenést mutattak (NÉMETH, KovÁCS, VAKLI, KOVÁCS és Zimmer, 2014). További vizsgálatokban érdemes lenne tisztázni a fenti gondolatmenet helyességét az LO arcfelismerési folyamatokban betöltött szerepével kapcsolatban. Továbbá prosopagnosiás személyeknél a különböző zajos ingerekre (például zajos autók vs. zajos arcok) adott agyi aktivitás vizsgálatával a zajfeldolgozó egység kategóriaspecifikussága is tesztelhető lenne.

\section{REJTETT FELISMERÉS}

A prosopagnosia és a Capgras-téveszme (áttekintésért lásd ELLIS és LEWIS, 2001; HIRSTEIN és RAMACHANDRAN, 1997) ráirányítja a figyelmünket az arcfelismerés tudatos és tudattalan folyamataira is. A prosopagnosiások nem ismernek fel általuk ismert személyeket azok arca alapján, de vannak bizonyos esetek, ahol vannak jelei a felismerési funkciók működésének (rejtett felismerés), amelyek azonban elégtelenek a tudatos felismeréshez. Ezzel szemben a Capgras-téveszmés betegek tudatosan felismerik ismerőseiket/hírességeket arc alapján, de nem képesek a személlyel kapcsolatos érzelmi tartalmak elérésére.

A perceptuális folyamatok épsége összefügg a rejtett felismerés viselkedéses eredményeivel (SCHWEINBERGER és BURTON, 2003), ami érthető, hiszen ha már a perceptuális funkciók képtelenek a bejövő ingert fiziológiás neurális kóddá alakítani, nem jöhet létre olyan reprezentáció, amit a feldolgozás további szakaszában illeszteni lehetne a már kialakult emléknyomokkal.

Régóta ismert, hogy érzelmeket kiváltó ingerek, ilyen lehet például szeretteink vagy épp gyülölt ellenségeink arcképe is, a vegetatív idegrendszeren keresztül a megnövekedett verejtékezés miatt befolyással vannak a bőr ellenállására (GBR galvános bőrreakció) (TRANEL, FowlEs és DAMASIO, 1985). Bizonyos prosopagnosiás személyek is mutatják a rejtett felismerés jeleit, azaz például nem tudják, hogy kit látnak, de vegetatív válaszaik szelektívek ismerős/ismeretlen arcokra, ami a 
tudatos és a nem tudatos arcfelismerés disszociációjára utal (J. J. BARTON és Cherkasova, 2003; J. J. Barton, Cherkasova és O'Connor, 2001; Simon és mtsai, 2011). Vannak esetek, ahol fordítva, a jól működő tudatos arcfelismerés agyi hálózatrendszere és a kiterjesztett rendszer érzelmi feldolgozást végző agyterületeinek (például amygdala) összeköttetési problémájáról van szó (ELLIS, YOUNG, QUAYLE és DE PAUW, 1997). A tudatos felismerésből (ez a személy az anyám) és a normális esetben ilyenkor kiváltódó érzelmek hiányából (és szeretnem kellene) adódó összeférhetetlenségnek köszönhetően, bizonyos esetekben kialakulhat a Capgrastéveszme (a 3.ábrán a 3-assal jelölt sérüléshez köthető zavar) (ELLIS és LEWIS, 2001). Capgras-téveszme esetén a kapcsolat jellegétől függően (ismerős arc vs. ismeretlen) a GBR-ben nem mérhető semmilyen különbség (HIRSTEIN és RAMACHANDRAN, 1997). Az esetek áttekintésével kirajzolódik egy újabb deficit, a multimodális személyfelismerési zavar. Az ilyen esetek abban közösek, hogy a különböző modalitású feldolgozásokból származó információk nem aktiválják megfelelően a bal temporalis lebeny elülső területét, így az illető hang, arc, mozgás stb. alapján is nehezen vagy egyáltalán nem ismeri fel hozzátartozóit, ismerőseit (GAINOTTI, 2013). Annak megállapításához, hogy a prosopagnosia milyen arányban társul más modalitásokban is megjelenő személyfelismerési zavarokkal, további vizsgálatok szükségesek.

\section{ÖSSZEFOGLALÁS}

Az elmúlt 20 évben a prosopagnosia iránti érdeklődés folyamatosan növekszik, az is látható azonban, hogy a zavar teljes feltérképezéséhez sok munkára van még szükség. A többnyire elszigetelt, egyedi esetek bemutatásával ez idáig sok inkonzisztens eredményhez jutottunk, amelyek értelmezését tovább nehezítik a különböző vizsgálatok közötti módszertani különbségek. Az is nyilvánvaló, hogy a prosopagnosia ezen kutatás-módszertani különbségek ellenére sem tekinthető egységes zavarnak, az érdemi előrelépéshez, a zavar megalapozott osztályozásához azonban jól kontrollált és legfőképpen nagy elemszámú vizsgálatokra van szükség, ahol ugyanazon prosopagnosiás és kontrollszemélyekkel több különböző kísérletből, tesztből származó eredmények is rendelkezésre állnak.

\section{RÖVIDÍTÉSEK JEGYZÉKE}

$\begin{array}{ll}\text { aTL } & -\begin{array}{l}\text { temporalis lebeny elülső területe } \\ \text { (anterior temporal lobe) }\end{array} \\ \text { AMG } & - \text { amygdala } \\ \text { DCM } & -\begin{array}{l}\text { a funkcionális konnektivitás modellezése } \\ \text { (dynamic causal modelling) }\end{array} \\ \text { EEG } & - \text { elektroenkefalográf } \\ \text { EKP } & - \text { eseményhez kötött kiváltott potenciál }\end{array}$




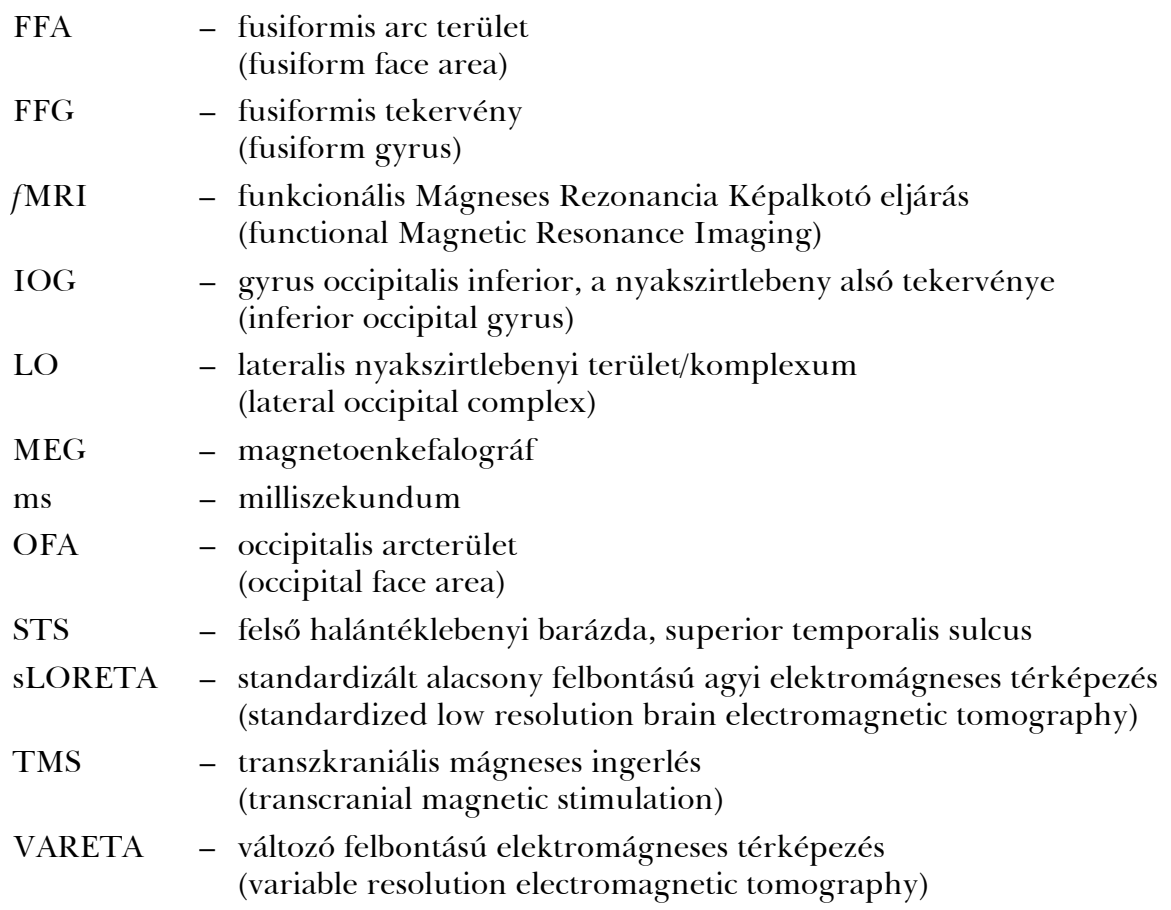

\section{IRODALOM}

Akechi, H., Kikuchi, Y., Tojo, Y., Osanai, H., \& Hasegawa, T. (2014). Neural and behavioural responses to face-likeness of objects in adolescents with autism spectrum disorder. Sci Rep, 4, 3874.

Alonso-Prieto, E., Caharel, S., Henson, R., \& Rossion, B. (2011). Early (n170/m170) face-sensitivity despite right lateral occipital brain damage in acquired prosopagnosia. Frontiers in Human Neuroscience, 5, 138.

ANTAL A. (2003). Virtuális léziós technikák: a transzkraniális mágneses és egyenáramingerlés és néhány felhasználásuk. In PléH Cs., KovÁcs G. és GulYÁs B. (szerk.), Kognitív idegtudomány (103-125). Budapest: Osiris Kiadó.

AVIDAN, G., \& BEHRMANN, M. (2009). Functional MRI reveals compromised neural integrity of the face processing network in congenital prosopagnosia. Current Biology, 19(13), 1146-1150.

Bala, A., Iwanski, S., Zylkowski, J., Jaworski, M., Seniow, J., \& Marchel, A. (2014). Visual disorders, the prosopometamorphopsia and prosopagnosia type in the early days after the onset of brain hemorrhagic stroke - a case report. Neurocase. doi: 10.1080/13554794.2014.892999

Bankó, E. M., GÁl, V., KÖrTvélyes, J., KovÁCs, G., \& VidnyÁnszKy, Z. (2011). Dissociating the effect of noise on sensory processing and overall decision difficulty. Journal of Neuroscience, 31(7), 2663-2674. 
Barton, J. J., \& Cherkasova, M. (2003). Face imagery and its relation to perception and covert recognition in prosopagnosia. Neurology, 61(2), 220-225.

Barton, J. J., Cherkasova, M. V., \& O’Connor, M. (2001). Covert recognition in acquired and developmental prosopagnosia. Neurology, 57(7), 1161-1168.

Barton, J. J., Cherkasova, M. V., Press, D. Z., Intriligator, J. M., \& Connor, M. O. (2003). Developmental prosopagnosia: A study of three patients. Brain and Cognition, $51,12-30$.

Behrmann, M., \& AvidAn, G. (2005). Congenital prosopagnosia: face-blind from birth. Trends in Cognitive Sciences, 9(4), 180-187.

Behrmann, M., Avidan, G., GaO, F., \& Black, S. (2007). Structural imaging reveals anatomical alterations in inferotemporal cortex in congenital prosopagnosia. Cereb Cortex, 17(10), 2354-2363.

Bentin, S., Allison, T., Puce, A., Perez, E., \& McCarthy, G. (1996). Electrophysiological Studies of Face Perception in Humans. Journal of Cognitive Neuroscience, 8(6), 551-565.

Bentin, S., Degutis, J. M., D’Esposito, M., \& Robertson, L. C. (2007). Too many trees to see the forest: performance, event-related potential, and functional magnetic resonance imaging manifestations of integrative congenital prosopagnosia. Journal of Cognitive Neuroscience, 19(1), 132-146.

Bentin, S., \& Deouell, L. Y. (2000). Structural encoding and identification in face processing: erp evidence for separate mechanisms. Cogn Neuropsychol, 17(1), 35-55.

Bentin, S., Deouell, L. Y., \& Soroker, N. (1999). Selective visual streaming in face recognition: evidence from developmental prosopagnosia. Neuroreport, 10(4), 823-827.

Benton, A. L. (1984). Facial recognition. In L. Costa \& O. Spreen (Eds.), Studies in Neuropsychology. Selected Papers of Arthur Benton (224-235). New York: Oxford University Press.

Bobes, M. A., Lopera, F., D'iaz Comas, L., Galan, L., Carbonell, F., Bringas, M. L., \& VALDES-SosA, M. (2004). Brain potentials reflect residual face processing in a case of prosopagnosia. Cognitive Neuropsychology, 21, 691-718.

Bodamer, J. (1947). Die Prosop-Agnosie. (Die Agnosie des Physiognomieerkennens. [1990].) Archiv für Psychiatrie und Nervenkrankheiten, 179, 6-53.

Bouvier, S. E., \& Engel, S. A. (2006). Behavioral deficits and cortical damage loci in cerebral achromatopsia. Cerebral Cortex, 16(2), 183-191.

Bowles, D. C., McKone, E., Dawel, A., Duchaine, B., Palermo, R., Schmalzl, L., ... Yovel, G. (2009). Diagnosing prosopagnosia: effects of ageing, sex, and participantstimulus ethnic match on the Cambridge Face Memory Test and Cambridge Face Perception Test. Cognitive Neuropsychology, 26(5), 423-455.

Breen, N., Caine, D., \& Coltheart, M. (2000). Models of face recognition and delusional misidentification: A critical review. Cognitive Neuropsychology, 17, 55-71.

Bruce, V., \& Young, A. (1986). Understanding face recognition. British Journal of Psychology, 77, 305-327.

Burton, A. M., Bruce, V., \& Hancock, P. J. B. (1999). From pixels to people: A model of familiar face recognition. Cognitive Science, 23, 1-31.

Busigny, T., Graf, M., Mayer, E., \& Rossion, B. (2010). Acquired prosopagnosia as a face-specific disorder: ruling out the general visual similarity account. Neuropsychologia, 48(7), 2051-2067. 
Busigny, T., Joubert, S., Felician, O., Ceccaldi, M., \& Rossion, B. (2010). Holistic perception of the individual face is specific and necessary: evidence from an extensive case study of acquired prosopagnosia. Neuropsychologia, 48(14), 4057-4092.

Busigny, T., \& Rossion, B. (2010). Holistic processing impairment can be restricted to faces in acquired prosopagnosia: evidence from the global/local Navon effect. Journal of Neuropsychology, 5(Pt 1), 1-14.

Caharel, S., Fiori, N., Bernard, C., Lalonde, R., \& Rebai, M. (2006). The effects of inversion and eye displacements of familiar and unknown faces on early and late-stage ERPs. International Journal of Psychophysiology, 62(1), 141-151.

Caharel, S., Poiroux, S., Bernard, C., Thibaut, F., Lalonde, R., \& Rebai, M. (2002). ERPs associated with familiarity and degree of familiarity during face recognition. International Journal of Neuroscience, 112(12), 1499-1512.

Dai, J., Zhai, H., Wu, H., Yang, S., Cacioppo, J. T., Cacioppo, S., \& Luo, Y. J. (2014). Maternal face processing in Mosuo preschool children. Biological Psychology. doi: 10.1016/j.biopsycho.2014.03.001

Dakin, S. C., Hess, R. F., Ledgeway, T., \& AChtman, R. L. (2002). What causes nonmonotonic tuning of $f$ MRI response to noisy images? Current Biology, 12(14), R476-477; author reply R478.

Dalrymple, K. A., Oruc, I., Duchaine, B., Pancaroglu, R., Fox, C. J., Iaria, G., ... BarTON, J. J. (2011). The anatomic basis of the right face-selective N170 IN acquired prosopagnosia: a combined ERP/fMRI study. Neuropsychologia, 49(9), 2553-2563.

Damasio, A. R., Damasio, H., \& Van Hoesen, G. W. (1982). Prosopagnosia: anatomic basis and behavioral mechanisms. Neurology, 32(4), 331-341.

Davies-Thompson, J., Pancaroglu, R., \& Barton, J. (2014). Acquired prosopagnosia: structural basis and processing impairments. Front Biosci (Elite Ed), 6, 159-174.

De Gelder, B., \& STekelenburG, J. J. (2005). Naso-temporal asymmetry of the N170 for processing faces in normal viewers but not in developmental prosopagnosia. Neuroscience Letters, 376(1), 40-45.

De HaAn, E. H., \& CAmpbell, R. (1991). A fifteen year follow-up of a case of developmental prosopagnosia. Cortex, 27(4), 489-509.

De Renzi, E., Faglioni, P., Grossi, D., \& Nichelli, P. (1991). Apperceptive and associative forms of prosopagnosia. Cortex, 27(2), 213-221.

Degutis, J. M., Bentin, S., Robertson, L. C., \& D’Esposito, M. (2007). Functional plasticity in ventral temporal cortex following cognitive rehabilitation of a congenital prosopagnosic. Journal of Cognitive Neuroscience, 19(11), 1790-1802.

DeHaan, E., Young, A. W., \& Newcombe, F. (1991). A dissociation between the sense of familiarity and access to semantic information concerning familiar people. European Journal of Cognitive Psychology, 3, 51-67.

Deruelle, C., Mancini, J., Livet, M. O., Casse-Perrot, C., \& De Schonen, S. (1999). Configural and local processing of faces in children with Williams syndrome. Brain Cogn, 41(3), 276-298.

Diamond, R., \& CARey, S. (1986). Why faces are and are not special: an effect of expertise. Journal Exp Psychol Gen, 115(2), 107-117.

Dinkelacker, V., Gruter, M., Klaver, P., Gruter, T., Specht, K., Weis, S., ... FernanDEZ, G. (2011). Congenital prosopagnosia: multistage anatomical and functional deficits in face processing circuitry. Journal of Neurology, 258(5), 770-782. 
Dobel, C., Bolte, J., Aicher, M., \& Schweinberger, S. R. (2007). Prosopagnosia without apparent cause: overview and diagnosis of six cases. Cortex, 43(6), 718-733.

Dobel, C., Junghofer, M., \& Gruber, T. (2011). The role of gamma-band activity in the representation of faces: reduced activity in the fusiform face area in congenital prosopagnosia. PLoS One, 6(5), e19550.

Dobel, C., Putsche, C., Zwitserlood, P., \& Junghofer, M. (2008). Early lefthemispheric dysfunction of face processing in congenital prosopagnosia: an MEG study. PLoS One, 3(6), e2326.

Duchaine, B. (2011). Developmental prosopagnosia: Cognitive, neural, and developmental investigations. In A. J. Calder, G. Rhodes, M. H. Johnson, \& J. V. Haxby (Eds.), The Oxford Handbook of face perception (821-838). Oxford: Oxford University Press.

Duchaine, B., Germine, L., \& NAKAyama, K. (2007). Family resemblance: ten family members with prosopagnosia and within-class object agnosia. Cognitive Neuropsychology, 24(4), $419-430$.

Duchaine, B. C. (2000). Developmental prosopagnosia with normal configural processing. Neuroreport, 11(1), 79-83.

Duchaine, B. C., \& Nakayama, K. (2006a). Developmental prosopagnosia: a window to content-specific face processing. Current Opinion in Neurobiology, 16(2), 166-173.

Duchaine, B. C., \& Nakayama, K. (2006b). Developmental prosopagnosia: a window to content-specific face processing. Curr Opin Neurobiol, 16(2), 166-173.

EIMER, M. (2000a). Effects of face inversion on the structural encoding and recognition of faces. Evidence from event-related brain potentials. Cognitive Brain Research, 10(1-2), $145-158$.

EIMER, M. (2000b). Event-related brain potentials distinguish processing stages involved in face perception and recognition. Clinical Neurophysiology, 111(4), 694-705.

EImer, M. (2011). The face-sensitivity of the n170 component. Front Hum Neurosci, 5, 119.

Eimer, M., \& McCarthy, R. A. (1999). Prosopagnosia and structural encoding of faces: evidence from event-related potentials. Neuroreport, 10(2), 255-259.

Ellis, H. D., \& Lewis, M. B. (2001). Capgras delusion: a window on face recognition. Trends Cogn Sci, 5(4), 149-156.

Ellis, H. D., Young, A. W., Quayle, A. H., \& De Pauw, K. W. (1997). Reduced autonomic responses to faces in Capgras delusion. Proceedings Biological sciences, 264(1384), 10851092.

Fernández-Bouzas, A., Harmony, T., Fernández, T., Silva-Pereyra, J., Valdés, P., Bosch, J., ... SAntiago, E. (2000). Sources of abnormal EEG activity in brain infarctions. Clinical Electroencephalography, 31, 165-169.

Flude, B. M., Ellis, A. W., \& KAY, J. (1989). Face processing and name retrieval in an anomic aphasic: Names are stored separately from semantic information about familiar people. Brain and Cognition, 11, 60-72.

Fox, C. J., IARIA, G., \& Barton, J. J. (2008). Disconnection in prosopagnosia and face processing. Cortex, 44(8), 996-1009.

GAINOTTI, G. (2013). Is the right anterior temporal variant of prosopagnosia a form of 'associative prosopagnosia' or a form of 'multimodal person recognition disorder'? $\mathrm{Neu}$ ropsychology Review, 23(2), 99-110. 
Gainotti, G., \& Marra, C. (2011). Differential contribution of right and left temporooccipital and anterior temporal lesions to face recognition disorders. Frontiers in Human Neuroscience, 5(55).

Gao, Z., Goldstein, A., Harpaz, Y., Hansel, M., Zion-Golumbic, E., \& Bentin, S. (2013). A magnetoencephalographic study of face processing: M170, gamma-band oscillations and source localization. Hum Brain Mapp, 34(8), 1783-1795.

Gobbini, M. I., \& Haxby, J. V. (2006). Neural response to the visual familiarity of faces. Brain Res Bull, 71(1-3), 76-82.

Gobbini, M. I., \& Haxby, J. V. (2007). Neural systems for recognition of familiar faces. Neuropsychologia, 45, 32-41.

Grice, S. J., Spratling, M. W., Karmiloff-Smith, A., Halit, H., Csibra, G., de HaAn, M., \& Johnson, M. H. (2001). Disordered visual processing and oscillatory brain activity in autism and Williams syndrome. Neuroreport, 12(12), 2697-2700.

Grill-Spector, K., Kourtzi, Z., \& Kanwisher, N. (2001). The lateral occipital complex and its role in object recognition. Vision Research, 41(10-11), 1409-1422.

Grueter, M., Grueter, T., Bell, V., Horst, J., Laskowski, W., Sperling, K., ... KenNerkneCht, I. (2007). Hereditary prosopagnosia: the first case series. Cortex, 43(6), 734-749.

GulYÁs B. (2003). Funkcionális képalkotó eljárások a kognitív idegtudományokban. In PléH Cs., Kovács G. és Gulyás B. (szerk.), Kognitív idegtudomány (103-125). Budapest: Osiris Kiadó.

Gulyás B. és Mórocz I. Á. (2008). Funkcionális képalkotó eljárások. In KÁLlAI J., Bende I., KARÁDI K. és RACSMÁNY M. (szerk.), Bevezetés a neuropszichológiába (45-63). Budapest: Medicina Könyvkiadó.

Hämäläinen, M., HaRi, R., Ilmoniemi, R. J., KnuUtila, J., \& LounasmaA, O. V. (1993). Magnetoencephalography - Theory, instrumentation, and applications to noninvasive studies of the working human brain. Review of Modern Physics, 65, 413-497.

Harris, A. M., Duchaine, B. C., \& Nakayama, K. (2005). Normal and abnormal face selectivity of the M170 response in developmental prosopagnosics. Neuropsychologia, 43(14), 2125-2136.

Haxby, J. V., Hoffman, E. A., \& Gobbini, M. I. (2000). The distributed human neural system for face perception. Trends in Cognitive Sciences, 4(6), 223-233.

Haxby, J. V., Hoffman, E. A., \& Gobbini, M. I. (2002). Human neural systems for face recognition and social communication. Biological Psychiatry, 51(1), 59-67.

Hecaen, H., \& Angelergues, R. (1962). Agnosia for faces (prosopagnosia). Arch Neurol, 7 , 92-100.

Henson, R. N., Goshen-Gottstein, Y., Ganel, T., Otten, L. J., Quayle, A., \& Rugg, M. D. (2003). Electrophysiological and haemodynamic correlates of face perception, recognition and priming. Cerebral Cortex, 13(7), 793-805.

Hirstein, W., \& RAMACHANDran, V. S. (1997). Capgras syndrome: a novel probe for understanding the neural representation of the identity and familiarity of persons. Proc Biol Sci, 264(1380), 437-444.

Itier, R. J., Alain, C., Sedore, K., \& Mcintosh, A. R. (2007). Early face processing specificity: it's in the eyes! Journal Cogn Neurosci, 19(11), 1815-1826.

ITIER, R. J., \& BATTY, M. (2009). Neural bases of eye and gaze processing: the core of social cognition. Neurosci Biobehav Rev, 33(6), 843-863. 
ITIER, R. J., \& TAYlor, M. J. (2004a). N170 or N1? Spatiotemporal differences between object and face processing using ERPs. Cerebral Cortex, 14(2), 132-142.

Itier, R. J., \& TAYLOR, M. J. (2004b). Source analysis of the N170 to faces and objects. Neuroreport, 15(8), 1261-1265.

Jemel, B., Schuller, A. M., Cheref-Khan, Y., Goffaux, V., Crommelinck, M., \& BruYER, R. (2003). Stepwise emergence of the face-sensitive N170 event-related potential component. Neuroreport, 14(16), 2035-2039.

JiAng, F., Dricot, L., Weber, J., Righi, G., TARr, M. J., Goebel, R., \& Rossion, B. (2011). Face categorization in visual scenes may start in a higher order area of the right fusiform gyrus: evidence from dynamic visual stimulation in neuroimaging. Journal Neurophysiol, 106(5), 2720-2736.

Kanwisher, N., McDermott, J., \& Chun, M. M. (1997). The fusiform face area: a module in human extrastriate cortex specialized for face perception. Journal Neurosci, 17(11), 4302-4311.

Kanwisher, N., \& Yovel, G. (2006). The fusiform face area: a cortical region specialized for the perception of faces. Philos Trans R Soc Lond B Biol Sci, 361(1476), 2109-2128.

KARMILOFF-SMiTH, A. (2009). Nativism versus neuroconstructivism: rethinking the study of developmental disorders. Dev Psychol, 45(1), 56-63.

Kennerknecht, I., Grueter, T., Welling, B., Wentzek, S., Horst, J., Edwards, S., \& Grueter, M. (2006). First report of prevalence of non-syndromic hereditary prosopagnosia (HPA). American Journal of Medical Genetics Part A, 140(15), 1617-1622.

Kennerknecht, I., Ho, N. Y., \& Wong, V. C. (2008). Prevalence of hereditary prosopagnosia (HPA) in Hong Kong Chinese population. American Journal of Medical Genetics Part A, $146 A$ (22), 2863-2870.

Kennerknecht, I., Plumpe, N., Edwards, S., \& Raman, R. (2007). Hereditary prosopagnosia (HPA): the first report outside the Caucasian population. Journal of Human Genetics, 52(3), 230-236.

KÉRI Sz. és GulYÁs B. (2003a). Elektrofiziológiai módszerek a kognitív idegtudományokban. In PléH Cs., Kovács G. és Gulyás B. (szerk.), Kognitív idegtudomány (81-96). Budapest: Osiris Kiadó.

KÉRI Sz. és GUlYÁs B. (2003b). Lokalizáció és lézióanalízis a kognitív idegtudományokban. In PléH Cs., Kovács G. és Gulyás B. (szerk.), Kognitív idegtudomány (67-80). Budapest: Osiris Kiadó.

Kloth, N., Dobel, C., Schweinberger, S. R., Zwitserlood, P., Bolte, J., \& Junghofer, M. (2006). Effects of personal familiarity on early neuromagnetic correlates of face perception. European Journal of Neuroscience, 24(11), 3317-3321.

Kloth, N., Itier, R. J., \& Schweinberger, S. R. (2013). Combined effects of inversion and feature removal on N170 responses elicited by faces and car fronts. Brain and Cognition, 81, 321-328.

Kosaka, H., Omori, M., Iidaka, T., Murata, T., Shimoyama, T., OKada, T., ... Wada, Y. (2003). Neural substrates participating in acquisition of facial familiarity: an $f$ MRI study. Neuroimage, 20(3), 1734-1742.

Kourtzi, Z., \& KANwisher, N. (2001). Representation of perceived object shape by the human lateral occipital complex. Science, 293(5534), 1506-1509.

Kress, T., \& DAum, I. (2003). Event-related potentials reflect impaired face recognition in patients with congenital prosopagnosia. Neuroscience Letters, 352, 133-136. 
Lee, Y., Duchaine, B., Wilson, H. R., \& Nakayama, K. (2010). Three cases of developmental prosopagnosia from one family: detailed neuropsychological and psychophysical investigation of face processing. Cortex, 46(8), 949-964.

Lerner, Y., Hendler, T., Ben-Bashat, D., Harel, M., \& Malach, R. (2001). A hierarchical axis of object processing stages in the human visual cortex. Cereb Cortex, 11(4), 287297.

Lissauer, H. (1890). Ein Fall von Seelenblindheiten nebst einen Beitrage zur Theorie derselben. Archiv für Psychiatrie and Nervenkrankenheiten, 21, 222-270.

LiU, J., Harris, A., \& Kanwisher, N. (2010). Perception of face parts and face configurations: an $f$ MRI study. Journal of Cognitive Neuroscience, 22(1), 203-211.

Mattson, A. J., Levin, H. S., \& Grafman, J. (2000). A case of prosopagnosia following moderate closed head injury with left hemisphere focal lesion. Cortex, 36(1), 125-137.

Mayer, E., \& Rossion, B. (2007). Prosopagnosia. In O. Godefroy, \& J. Bogousslavsky (Eds.), The Behavioral and Cognitive Neurology of Stroke (345-334). Cambridge: Cambridge University Press.

Meadows, J. C. (1974). The anatomical basis of prosopagnosia. Journal Neurol Neurosurg Psychiatry, 37(5), 489-501.

Minnebusch, D. A., Suchan, B., Ramon, M., \& DAum, I. (2007). Event-related potentials reflect heterogeneity of developmental prosopagnosia. European Journal of Neuroscience, 25(7), 2234-2247.

Morton, J., \& Johson, M. H. (1991). CONSPEC and CONLERN: A two-process theory of infant face recognition. Psychological Review, 98, 164-181.

Nagy, K., Greenlee, M. W., \& Kovacs, G. (2012). The lateral occipital cortex in the face perception network: an effective connectivity study. Frontiers in Psychology, 3, 141.

Németh, K., Kovács, P., Vakli, P., Kovács, G., \& Zimmer, M. (2014). Phase noise reveals early category-specific modulation of the event-related potentials. Front Psychol, 5, 367.

Németh, K., Zimmer, M., NAGy, K., Bankó, É., Vidnyánszky, Z., VAKli, P., \& Kovács, G. (2015). Altered BOLD response within the core face processing network in congenital prosopagnosia. Clinical Neuroscience, 68(5-6), 199-211.

Németh, K., Zimmer, M., Schweinberger, S. R., Vakli, P., \& Kovács, G. (2014). The background of reduced face specificity of n170 in congenital prosopagnosia. PLoS One, 9(7), e101393.

Palermo, R., Rivolta, D., Wilson, C. E., \& JefFery, L. (2011). Adaptive face space coding in congenital prosopagnosia: typical figural aftereffects but abnormal identity aftereffects. Neuropsychologia, 49(14), 3801-3812.

Palermo, R., Willis, M. L., Rivolta, D., McKone, E., Wilson, C. E., \& Calder, A. J. (2011). Impaired holistic coding of facial expression and facial identity in congenital prosopagnosia. Neuropsychologia, 49(5), 1226-1235.

PASCuAl-MarQui, R. D. (2002). Standardized low-resolution brain electromagnetic tomography (sLORETA): technical details. Methods Find Exp Clin Pharmacol, 24(Suppl D), 5-12.

Perrett, D. I., Smith, P. A., Potter, D. D., Mistlin, A. J., Head, A. S., Milner, A. D., \& Jeeves, M. A. (1985). Visual cells in the temporal cortex sensitive to face view and gaze direction. Proceedings of the Royal Society of London, Series B: Biological Sciences, 223(1232), 293-317. 
Pitcher, D., Duchaine, B., Walsh, V., Yovel, G., \& Kanwisher, N. (2011). The role of lateral occipital face and object areas in the face inversion effect. Neuropsychologia, 49(12), 3448-3453.

Pitcher, D., Walsh, V., \& Duchaine, B. (2011). The role of the occipital face area in the cortical face perception network. Experimental Brain Research, 209(4), 481-493.

Ramon, M., Busigny, T., \& Rossion, B. (2010). Impaired holistic processing of unfamiliar individual faces in acquired prosopagnosia. Neuropsychologia, 48(4), 933-944.

RÉvész G. (szerk.) (2010). Az emberi Arc. Pécs: Pro Pannónia Kiadó.

RIGHART, R., \& DE GELDER, B. (2007). Impaired face and body perception in developmental prosopagnosia. Proceedings of the National Academy of Sciences USA, 104(43), 1723417238.

Rivolta, D., Palermo, R., \& Schmalzl, L. (2013). What is overt and what is covert in congenital prosopagnosia? Neuropsychol Rev, 23(2), 111-116.

Rivolta, D., Palermo, R., Schmalzl, L., \& Coltheart, M. (2012). Covert face recognition in congenital prosopagnosia: A group study. Cortex, 48, 344-352.

Rivolta, D., Palermo, R., Schmalzl, L., \& Williams, M. A. (2012). Investigating the features of the m170 in congenital prosopagnosia. Frontiers in Human Neuroscience, 6, 45.

Rivolta, D., Schmalzl, L., Coltheart, M., \& Palermo, R. (2010). Semantic information can facilitate covert face recognition in congenital prosopagnosia. Journal of Clinical and Experimental Neuropsychology, 32(9), 1002-1016.

Rossion, B. (2008). Constraining the cortical face network by neuroimaging studies of acquired prosopagnosia. Neuroimage, 40(2), 423-426.

Rossion, B., Caldara, R., Seghier, M., Schuller, A. M., Lazeyras, F., \& Mayer, E. (2003). A network of occipito-temporal face-sensitive areas besides the right middle fusiform gyrus is necessary for normal face processing. Brain, 126(Pt 11), 2381-2395.

Rossion, B., Dricot, L., Goebel, R., \& Busigny, T. (2011). Holistic face categorization in higher order visual areas of the normal and prosopagnosic brain: toward a nonhierarchical view of face perception. Frontiers in Human Neuroscience, 4, 225.

Rossion, B., Gauthier, I., Tarr, M. J., Despland, P., Bruyer, R., Linotte, S., \& CromMELINCK, M. (2000). The N170 occipito-temporal component is delayed and enhanced to inverted faces but not to inverted objects: an electrophysiological account of facespecific processes in the human brain. Neuroreport, 11(1), 69-74.

Rossion, B., \& JACQUES, C. (2011). The N170: understanding the time-course of face perception in the human brain. In S. LUCK, \& E. KAPPENMAN (Eds.), The Oxford Handbook of ERP Components (115-141.). Oxford: Oxford University Press.

Rossion, B., Schiltz, C., \& Crommelinck, M. (2003). The functionally defined right occipital and fusiform "face areas" discriminate novel from visually familiar faces. Neuroimage, 19(3), 877-883.

Rossion, B., Schiltz, C., Robaye, L., Pirenne, D., \& Crommelinck, M. (2001). How does the brain discriminate familiar and unfamiliar faces?: a PET study of face categorical perception. Journal Cogn Neurosci, 13(7), 1019-1034.

Rotshtein, P., Henson, R. N., Treves, A., Driver, J., \& Dolan, R. J. (2005). Morphing Marilyn into Maggie dissociates physical and identity face representations in the brain. Nature Neuroscience, 8(1), 107-113.

Rousselet, G. A., Husk, J. S., Bennett, P. J., \& Sekuler, A. B. (2007). Single-trial EeG dynamics of object and face visual processing. Neuroimage, 36(3), 843-862. 
Rousselet, G. A., Husk, J. S., Bennett, P. J., \& Sekuler, A. B. (2008). Time course and robustness of ERP object and face differences. Journal Vis, 8(12), 3 1-18.

Rousselet, G. A., Pernet, C. R., Bennett, P. J., \& Sekuler, A. B. (2008). Parametric study of EEG sensitivity to phase noise during face processing. BMC Neuroscience, 9, 98.

Schiltz, C., Sorger, B., Caldara, R., Ahmed, F., Mayer, E., Goebel, R., \& Rossion, B. (2006). Impaired face discrimination in acquired prosopagnosia is associated with abnormal response to individual faces in the right middle fusiform gyrus. Cerebral Cortex, 16(4), 574-586.

Schmalzl, L., Palermo, R., \& Coltheart, M. (2008). Cognitive heterogeneity in genetically based prosopagnosia: a family study. Journal of Neuropsychology, 2, 99-117.

Schmalzl, L., Palermo, R., Green, M., Brunsdon, R., \& Coltheart, M. (2008). Training of familiar face recognition and visual scan paths for faces in a child with congenital prosopagnosia. Cogn Neuropsychol, 25(5), 704-729.

Schwarzer, G., Huber, S., Gruter, M., Gruter, T., Gross, C., Hipfel, M., \& KennerKNECHT, I. (2007). Gaze behaviour in hereditary prosopagnosia. Psychol Res, 71(5), 583 590.

SCHWEInBerger, S. R. (2011). Neurophysiological correlates of face perception. In A. J. Calder, G. Rhodes, M. H. Johnson, \& J. V. Haxby (Eds.), Handbook of Face Perception (345-366). Oxford: Oxford University Press.

Schweinberger, S. R., \& Burton, A. M. (2003). Covert recognition and the neural system for face processing. Cortex, 39(1), 9-30.

Schweinberger, S. R., Pickering, E. C., Jentzsch, I., Burton, A. M., \& Kaufmann, J. M. (2002). Event-related brain potential evidence for a response of inferior temporal cortex to familiar face repetitions. Brain Res Cogn Brain Res, 14(3), 398-409.

SÉRA L. (2008). Tárgy- és arcfelismerési zavarok. In KÁllai J., BEndE I., KARÁdi K. és RACSMÁNy M. (szerk.), Bevezetés a neuropszichológiába (230-241). Budapest: Medicina Könyvkiadó Zrt.

Simon, S. R., Khateb, A., Darque, A., Lazeyras, F., Mayer, E., \& Pegna, A. J. (2011). When the brain remembers, but the patient doesn't: converging $f$ MRI and EEG evidence for covert recognition in a case of prosopagnosia. Cortex, 47(7), 825-838.

Singer, W. (2001). Consciousness and the binding problem. Ann N Y Acad Sci, 929, 123146.

Solomon-Harris, L. M., Mullin, C. R., \& Steeves, J. K. (2013). TMS to the "occipital face area" affects recognition but not categorization of faces. Brain and Cognition, 83(3), 245-251.

Steeves, J. K., Culham, J. C., Duchaine, B. C., Pratesi, C. C., Valyear, K. F., Schindler, I., .. GoOdale, M. A. (2006). The fusiform face area is not sufficient for face recognition: evidence from a patient with dense prosopagnosia and no occipital face area. Neuropsychologia, 44(4), 594-609.

Stollhoff, R., Jost, J., Elze, T., \& Kennerknecht, I. (2010). The early time course of compensatory face processing in congenital prosopagnosia. PLoS One, 5(7), el 1482.

Takahashi, N., Kawamura, M., Hirayama, K., Shiota, J., \& Isono, O. (1995). Prosopagnosia: a clinical and anatomical study of four patients. Cortex, 31(2), 317-329.

Thomas, A. L., Lawler, K., Olson, I. R., \& Aguirre, G. K. (2008). The Philadelphia Face Perception Battery. Archives of Clinical Neuropsychology, 23(2), 175-187. 
Thomas, C., Avidan, G., Humphreys, K., Jung, K. J., GaO, F., \& Behrmann, M. (2009). Reduced structural connectivity in ventral visual cortex in congenital prosopagnosia. Nature Neuroscience, 12(1), 29-31.

Tong, F., \& NAKAYAMa, K. (1999). Robust representations for faces: evidence from visual search. Journal Exp Psychol Hum Percept Perform, 25(4), 1016-1035.

TOWler, J., \& Eimer, M. (2012). Electrophysiological studies of face processing in developmental prosopagnosia: neuropsychological and neurodevelopmental perspectives. Cognitive Neuropsychology, 29(5-6), 503-529.

Towler, J., Gosling, A., Duchaine, B., \& Eimer, M. (2012). The face-sensitive N170 component in developmental prosopagnosia. Neuropsychologia, 50(14), 3588-3599.

Tranel, D., Fowles, D. C., \& Damasio, A. R. (1985). Electrodermal discrimination of familiar and unfamiliar faces: a methodology. Psychophysiology, 22(4), 403-408.

VAlentine, T., \& BRUCE, V. (1986). The effect of race, inversion and encoding activity upon face recognition. Acta Psychologica, 61(3), 259-273.

Watanabe, S., Kakigi, R., \& Puce, A. (2003). The spatiotemporal dynamics of the face inversion effect: a magneto- and electro-encephalographic study. Neuroscience, 116(3), 879-895.

Wurtz, R. H., \& Kandel, E. R. (2000). Perception of Motion, Depth, and Form. In E. R. Kandel, J. H. Schwartz, J. T. M., S. A. Siegelbaum, \& A. J. Hudspeth (Eds.), Principles of Neural Science (4 ed.) (548-571). New York: McGraw-Hill.

YIN, R. K. (1969). Looking at upside-down faces. Journal of Experimental Psychology, 81, 141145.

Zimmer M. (2013). Arcészlelés. Budapest: Akadémiai Kiadó.

\title{
THE CLASSIFICATION OF FACE RECOGNITION DISORDERS IN LIGHT OF THE ETIOLOGICAL FACTORS, THE NEUROSCIENTIFIC AND THE BEHAVIOURAL FINDINGS
}

\author{
NÉMETH, KORNÉL - ZIMMER, MÁRTA
}

Prosopagnosia is a disorder of recognition of familiar faces, without visual or cognitive dysfunction. While the acquired type is primarily due to the injury of occipito-temporal areas, the neural background of the congenital form seems to be more heterogeneous. In addition to the variability in neurological dysfunctions, symptom severity also shows high interindividual variability. Research on face recognition disorder is raising continuously in the past 20 years, however, since these investigations focus mainly on individual and unrelated cases, the conclusions remain quite limited. Based on these studies we cannot come to unequivocal conclusions, nevertheless the diversity of the results indicates the presence of different subtypes of the prosopagnosia. On the analogy of the classification of the object recognition disorders, the possibility to form apperceptive and associative subgroups emerges. One can also assume that prosopagnosia is a spectral deficit. The present paper reviews the possible classifications of prosopagnosia. Finally, we emphasize the importance of the differentiation and the considerations that would be useful for the understanding of face recognition disorders.

Key words: face recognition disorders, prosopagnosia, covert face-recognition, N170 